\title{
The effect of surface flooding on the
}

\section{physical-biogeochemical dynamics of a warm core eddy off southeast Australia.}

\author{
Mark E. Baird ${ }^{\text {a,c,* }}$ Iain M. Suthers ${ }^{d, c}$ David A. Griffin ${ }^{\mathrm{e}}$ \\ Ben Hollings ${ }^{\mathrm{f}}$ Charitha Pattiaratchi ${ }^{\mathrm{f}}$ Jason D. Everett ${ }^{\mathrm{d}, \mathrm{c}}$ \\ Moninya Roughan ${ }^{\text {b,c }}$ Kadija Oubelkheir ${ }^{\mathrm{g}}$ Martina Doblin ${ }^{\mathrm{a}, \mathrm{c}}$ \\ a Plant Functional Biology and Climate Change Cluster, Faculty of Science, \\ University of Technology Sydney, PO Box 123 Broadway, Sydney NSW 200\%, \\ Australia \\ ${ }^{\mathrm{b}}$ Coastal and Regional Oceanography Laboratory, School of Mathematics and \\ Statistics, University of NSW, Sydney NSW, 2052, Australia \\ ${ }^{\mathrm{c}}$ Sydney Institute of Marine Science, Mosman, NSW, 2088, Australia \\ d School of Biological, Earth and Environmental Sciences, University of NSW, \\ Sydney NSW, 2052, Australia \\ ${ }^{\text {e } C S I R O ~ M a r i n e ~ a n d ~ A t m o s p h e r i c ~ R e s e a r c h ~ a n d ~ W e a l t h ~ f r o m ~ O c e a n s ~ F l a g s h i p ~}$ \\ Program, GPO Box 1538 Hobart, Australia \\ ${ }^{\mathrm{f}}$ Centre for Water Research, University of Western Australia, 35 Stirling Highway, \\ Crawley, WA 6009, Australia \\ ${ }^{9}$ CSIRO Land and Water, Indooroopilly, QLD 4068, Australia
}

\begin{abstract}
Warm core eddies (WCEs) formed from the East Australian Current (EAC) play an important role in the heat, mass and biogeochemical budgets of the western Tasman Sea. The development and separation of an EAC WCE during July-December
\end{abstract}

Preprint submitted to EAC Special Issue of Deep-Sea Res. $\quad 4$ October 2010 
2008 was observed using remotely-sensed temperature, ocean colour and sea-level elevation, three Argo floats, a shipboard CTD, a shelf mooring array and a 15-day deployment of a Slocum glider. The eddy formed from an EAC meander during the first half of 2008 and in late August had a 275 m deep surface mixed layer. In the two months before separation in early December, fresher and warmer EAC water flooded the top of the eddy, submerging the winter mixed layer. The rate of vertical transport due to submergence was estimated to be between 1-6 Sv, at the time accounting for a significant fraction of the mean southward flow of the EAC. The core of the eddy had a surface chlorophyll $a$ concentration of $<0.4 \mathrm{mg} \mathrm{m}^{-3}$ throughout the observations. A 20-40 m thick pycnocline formed at the interface of the flooding surface waters and the submerged layer. Chlorophyll $a$ concentration in the pycnocline ranged from $0.5-2 \mathrm{mg} \mathrm{m}^{-3}$, with depth-integrated concentration ranging between $25-75 \mathrm{mg} \mathrm{m}^{-2}$. The development of a sub-surface maximum suggests that flooding increased light levels in the pycnocline. Elevated levels of coloured dissolved organic matter in the submerged layer correspond to oxygen depletion, suggesting respiration of organic matter. A comparison is made with observations from WCEs in 1978 and 1997 in which, unusually, surface flooding did not occur, but solar heating stratified the top $50 \mathrm{~m}$. In the two eddies with surface capping, surface chlorophyll $a$ concentrations were an order of magnitude higher than the 2008 flooded eddy, but depth-integrated chlorophyll $a$ was similar. These findings suggest that EAC WCEs with relatively shallow surface flooding contain more phytoplankton biomass than surface images would suggest, with the vertical position of the chlorophyll a maximum depending on whether, and to what depth, the winter surface mixed layer is submerged.

Key words: anti-cyclonic eddy, East Australian Current, Tasman Sea, deep chlorophyll maximum, autonomous underwater glider,

\footnotetext{
* Corresponding author.
} 


\section{Introduction}

Mesoscale eddies are a common feature in the open ocean and in particular in boundary currents, where they are sometimes referred to as rings (Mann and Lazier, 2006). The water in a warm core eddy (WCE) is less dense than the surrounding water, elevating sea-level and creating a negative surface pressure gradient in the radial (outward) direction. The pressure gradient is roughly in geostrophic balance with the tangential velocity, which, in the Southern Hemisphere, results in a counter-clockwise rotation (Bakun, 2006).

A simple conceptual model of the biological dynamics of a WCE considers the warm water at the core of the eddy to be nutrient-poor relative to the surrounding waters. Colder nutrient-rich water at depth below the centre of the eddy does not mix readily with the less-dense surface waters, although vertical circulation at the edges may occur along lines of equal density (Bakun, 2006). In this simple model WCEs are biologically unproductive, but may have elevated production on their edge.

WCEs created by strong boundary currents, such as the Gulf Stream in the northwestern Atlantic (Franks et al., 1986) or the Kuroshio Current in the northwestern Pacific (Yoshimori and Kishi, 1994), are often more complicated than the simple conceptual model above. Formed by meanders of a warmcurrent in a surrounding cooler ocean, these boundary current WCEs can entrain continental shelf and slope waters with their associated biological communities. Additionally, convective cooling as they move poleward can result in vertical mixing events. Further complications can result from varying physical properties of the boundary current (Cresswell, 1983), surface wind-stress (Mahadevan et al., 2008) or eddy-eddy interactions (Nilsson and Cresswell, 1981). These physical complications, especially when they drive vertical circulation (Yoshimori and Kishi, 1994), can alter the biological dynamics within and surrounding an eddy. The understanding of biophysical processes in boundary 
current mesoscale eddies may need to be tailored for each of the major current systems (e.g. Waite et al. (2007)).

The role of mesoscale processes and in particular WCEs (Hamon, 1965; Cresswell and Legeckis, 1986; Ridgway and Dunn, 2003; Brassington et al., in press) in the western Tasman Sea has long been recognised as both important and complex (Cresswell, 1983). WCEs off southeast Australia are formed from lownutrient sub-tropical water that is advected south as part of the East Australian Current (EAC). Eddies separate from the main flow intermittently, with a mean interval of 90-180 days (Mata et al., 2006; Wilkin and Zhang, 2007), and generally migrate parallel to the Australian coast in a poleward direction. The path of an individual eddy can be complicated by reabsorption by the EAC (Nilsson and Cresswell, 1981), coalescence of one or more eddies (Cresswell, 1982), or injections of filaments of surrounding water into the eddy (Scott, 1981; Cresswell, 1983).

The biological processes within (Tranter et al., 1980; Griffiths and Wadley, 1986) and surrounding (Tranter et al., 1983, 1986; Young, 1989) EAC WCEs were extensively studied between 1975-82. During this time CSIRO produced a sequential naming of eddies that was adopted consistently by authors at the time (Airey, 1983). The differences in phytoplankton species from within and surrounding an EAC WCE (Eddy Mario) was found to be minor, although concentrations were elevated when compared to the tropical Coral Sea water from which it had formed (Jeffrey and Hallegraeff, 1987). In contrast, crustaceans inside another EAC WCE (Eddy P) was a mixture of warm-water and cold-water species and was different to the crustacean fauna in either the Tasman Sea or the Coral Sea (Griffiths and Wadley, 1986). It has also been proposed that EAC WCEs result in enhanced fish catches (Young et al., 2001). EAC WCEs are not simply anti-clockwise rotating masses of Coral Sea water found anomalously south, but have dynamic physical processes that drive biological processes. 
The biological processes in two eddies, Eddy F in 1978 and Eddy J in 1980, were carefully investigated for their contrasting biological response. In Eddy F there was anomalously-high chlorophyll $a$ in the surface mixed layer (Tranter et al., 1980; Jeffrey and Hallegraeff, 1980). Tranter et al. (1980) explained the surface phytoplankton bloom by the easing of light limitation of phytoplankton growth in the eddy. Initially Eddy F had a > 200 m deep surface mixed layer. In late spring solar heating increased the water temperature near the surface, forming a surface mixed layer to $50 \mathrm{~m}$. Phytoplankton in the top $50 \mathrm{~m}$ were able to utilise the high nutrients remaining from winter. Surface chlorophyll $a$ concentrations were close to $1 \mathrm{mg} \mathrm{m}^{-3}$ and depth-integrated chlorophyll $a$ ranged between 22-55 $\mathrm{mg} \mathrm{m}^{-2}$ (Jeffrey and Hallegraeff, 1980). Tranter et al. (1980) referred to the processes of surface stratification due to solar heating as capping.

In the second eddy, Eddy J, a deep surface mixed layer in winter resulted in light limitation of phytoplankton growth, and the layer remained nutrient replete. In spring a surface filament of fresher and warmer EAC water encircled the existing eddy. The fresher water moved radial towards the centre of the eddy, submerging the original surface mixed layer (Tranter et al., 1982). When the original surface layer was submerged, it retained the temperature, salinity and nutrient concentration it had at the surface. The waters that flooded the eddy were nutrient deplete and had low surface chlorophyll $a$ concentrations. Even though Eddy J was more stratified than Eddy F, surface chlorophyll $a$ concentration was lower due to the different stratifying processes. Tranter et al. (1982) referred to the processes of a lighter filament of EAC water flowing onto the top of an existing eddy and submerging the original surface mixed layer as surface flooding.

All previous studies of the biological response in EAC WCEs were undertaken before the newly-increased capacity in remotely-sensed observations and high-resolution vertical profiling made available through the Australian Inte- 
grated Marine Observing System (IMOS). In particular, autonomous underwater gliders with bio-optical sensors are providing new insights into both physical and biological properties of sub-mesoscale phenomena (Niewiadomska et al., 2008).

This paper details observations of an EAC WCE using remotely-sensed temperature, ocean colour and sea-level elevation, three Argo floats, a shipboard CTD, a shelf mooring array and a 15-day deployment of a Slocum glider. The paper focuses on quantifying the phytoplankton response to surface flooding in the $2008 \mathrm{WCE}$, and comparing this response to those observed in other eddies in which surface flooding or capping occurred.

The paper is organised as follows. Material and Methods details the observational platforms that were used in this study. The Results is split into three sections. The first section analyses the formation and surface flooding of the eddy using data from the shipboard CTD, satellite remote-sensing and the Argo floats. The next two sections consider the physical and biogeochemical characteristics of the eddy after it has separated from the EAC flow. In the Discussion, the effect of light limitation on phytoplankton response to surface

flooding is considered, and estimates of biogeochemical processes undertaken. Finally, a comparison is made with two eddies that did not incur surface flooding, but instead developed a surface cap.

\section{Material and Methods}

Remotely-sensed observations. Surface temperature and colour data was extracted from the NASA Ocean Color website. MODIS data used is processed to Level 2 (temperature and chlorophyll $a$ algorithms applied on the orbital swath), while the SeaWiFS and CZCS data are further processed by spatial interpolation onto a regular grid (Level 3). Satellite altimeter data were provided 
by NASA/CNES (Topex/Poseidon, Jason-1, -2) and ESA (ERS2, ENVISAT) and mapped for the Australian region as described by Deng et al. (2010).

Glider mission. A Slocum glider was deployed off Port Stephens $\left(32^{\circ} 44^{\prime} \mathrm{S}\right.$, $152^{\circ} 14^{\prime} \mathrm{E}$ ) on the southeast Australian coast at 10:55 am on the 25 November 2008 and retrieved off Jervis Bay $\left(35^{\circ} 3^{\prime} \mathrm{S}, 151^{\circ} 16^{\prime} \mathrm{E}\right)$ on the 11 December 2008 (Fig. 1). The Slocum glider is an autonomous underwater vehicle that uses changes in buoyancy to move in a sawtooth trajectory with a forward velocity of $0.25-0.4 \mathrm{~m} \mathrm{~s}^{-1}$. The glider generally undulated between the surface and $180 \mathrm{~m}$, depth permitting. For a period between the 5-7 December the glider's maximum depth was reduced to $100 \mathrm{~m}$ to aid navigation. The glider path was primarily determined by the ambient current, which initially advected it south in a filament of the EAC which was flooding the surface of the WCE. The glider velocity relative to the flow was generally steered toward the centre of the eddy from deployment until the 3 December and then away from the centre until recovery. This produced a track that spiralled to close to centre of the eddy and then back to the perimeter while undertaking one rotation (Fig. 2).

The glider sensors included: a Seabird-CTD, a WETLabs BBFL2SLO 3 parameter optical sensor (measuring chlorophyll a, coloured dissolved organic matter (CDOM, Kirk (1994)) and backscatter at $660 \mathrm{~nm}$ ) and an Aanderaa oxygen optode. The most recent calibration of the optode was a four point factory calibration undertaken on the 21st September 2007 and which was found to have an accuracy of $\pm 5 \%$.

The depth-averaged ocean current relative to the ground is calculated using GPS co-ordinates at each surfacing ( $\sim 4$ hourly), and an estimate of glider velocity relative to the flow.

The effect of thermal lag on calculations of salinity from conductivity have been corrected using the approach of Morison et al. (1994) with an e-folding 
time of the temperature error, $\tau$, of $14 \mathrm{~s}$ and the initial amplitude of the error for a unit change in temperature, $\alpha$, of 0.13 .

The WETLabs BBFL2SLO deployed on the Slocum glider determines fluorescence from excitation/emission wavelengths of 470/695 nm. Factory calibrations are used to convert fluorescence to chlorophyll $a$. In situ measured fluorescence intensity is reduced at high ambient light intensities, a process called non-photochemical quenching (Falkowski and Kolber, 1995; Sackmann et al., 2008). To correct for the reduced estimate of chlorophyll $a$ during daylight hours, a light-dependent correction of chlorophyll $a$ for the deployment has been developed: $c h l_{\text {cor }}=c h l_{\text {uncor }}\left(1+\frac{I_{z}}{300}\right)$ where $c h l_{\text {cor }}$ is the corrected estimate of chlorophyll $a, c h l_{\text {uncor }}$ is the estimate of chlorophyll $a$ without correction, and $I_{z}$ is the light at depth $z$ of the observation.

For the calculation of $I_{z}$, surface irradiance is calculated from orbital cycles (Brock, 1981) and a 6 hourly averaged reduction in surface irradiance due to atmospheric conditions obtained from the NCEP reanalysis (Kalnay et al., 1996). Light intensity below the surface is calculated considering surface albedo as a function of azimuth angle, refraction of light at the air/water interface and attenuation due to clear water and water column chlorophyll (Baird et al., 2007).

The value of $300 \mathrm{~W} \mathrm{~m}^{-2}$ in the above equation is based on minimising (1) the vertical gradient of chlorophyll $a$ in the top $40 \mathrm{~m}$ on the 1 December when the glider was close to the centre of the eddy; and (2) the difference between day and night time surface readings from 1-8 December. The approach of using in situ light intensity to correct for quenching is similar to Behrenfeld and Boss (2006) in that it uses light intensity and a one-parameter empirical fit. The approach applied in this paper slightly outperformed Behrenfeld and Boss (2006) for this deployment, probably due to the extreme light levels.

Shipboard CTD. During a RV Southern Surveyor cruise (SS10/2008) 47 CTD 
stations were undertaken primarily in shelf and slope waters between Broughton Island $\left(32^{\circ} 30^{\prime} \mathrm{S}\right)$ to the north and Sydney $\left(34^{\circ} \mathrm{S}\right)$ to the south. In this paper data is used from CTD station 12 located at $32^{\circ} 50^{\prime} \mathrm{S}, 154^{\circ} 00^{\prime} \mathrm{E}$ on the $14 \mathrm{Oc}$ tober 2008 at 12:30 am AEST (Fig. 1). The station was $\sim 72 \mathrm{~km}$ north of the centre of the EAC meander that develops into the WCE that is the focus of this paper.

Nutrient analysis of bottle samples followed techniques described by Cowley et al. (1999) and has an approximate accuracy of $0.02 \mu \mathrm{M}$. Oxygen from bottle samples were determined using titration with an accuracy of $0.02 \mathrm{ml} \mathrm{L}^{-1}$. The CTD was fitted with a Seabird SBE911 with dual conductivity and temperature sensors, a SBE43DO dissolved oxygen sensor, a Biospherical PAR sensor and the Chelsea AquaTracka Fluorometer. $\mathrm{CO}_{2}$ measurements at the CTD station were undertaken by an underway system using a General Oceanics Inc. automated system (Model 8050) as part of the IMOS Ships Of Opportunity (SOOP) program. Hassler et al. (in press) undertakes further analysis of the nutrient and phytoplankton observations during this cruise, and refers to CTD station 12 as Stn 3.

Argo floats. The vertical profiles of temperature and salinity from three Argo floats were used: 5901659 profile 10 on the 17 July; 5901619 profile 49 on the 23 August; and 5900562 profiles 147, 148 and 149 on the 20 and 30 October and the 10 November (Fig. 1). No Argo floats observed the eddy after separation. For salinity the adjusted salinity field from the Global Argo Data Repository was used. Comparison of adjusted salinity against nearby floats at $2000 \mathrm{~m}$ suggests that the archived adjusted salinity of float 5900562 was consistently 0.015 high (pers. comm. Esmee Van Wijk), and a correction was applied before use in this study.

Sydney mooring array. The Sydney mooring array consists of the Sydney Water Ocean Reference Station (ORS065) that has been maintained since 1991, 
and the IMOS moorings SYD100 and SYD140 that form a shore normal line extending from Bondi, Sydney $\left(33^{\circ} 55^{\prime} \mathrm{S}\right)$. Data has been used from the 11 November until the 8 December 2008. The ADCP on SYD140 failed between 11 November and 5 December.

Calculation of eddy period. The rotation rate of the eddy can be estimated from the curl of the velocity field, from Lagrangian paths or from tangential speed. Angular velocity, $\theta$, is given by half the vorticity (the curl of the velocity field) in radian per second. The time to complete one solid body rotation is given by $2 \pi / \theta$.

\section{Results}

\subsection{Eddy formation}

During 2008 WCEs separated from the main EAC flow in mid January and early December. The 11-month gap between separation events is much longer than the typical 90-180 day interval determined from multi-year analyses (Mata et al., 2006). The first WCE of 2008 separated on approximately 20 January as a result of its southward migration, and the simultaneous westward propagation of a cold core eddy at $33^{\circ} 30^{\prime} \mathrm{S}$. This study focuses on the 2nd eddy of 2008 which began to grow as a new meander after the first eddy had separated.

Calculated geostrophic surface currents based on satellite altimetry (not shown) indicate that for the first few months of 2008 the new meander received EAC waters from the north, and lost water to the south. By May 2008 the mean-

der, now centred at $33^{\circ} \mathrm{S}, 155^{\circ} \mathrm{E}$, directed flow primarily to the east as part of the Tasman Front Jet (not shown). This state in the eddy formation was still evident at the beginning of September by which time the centre had moved 
to $34^{\circ} \mathrm{S}, 154^{\circ} \mathrm{E}$ (Fig. $\left.1 \& 3 \mathrm{~A}\right)$.

On 17 July an Argo profile $\sim 48 \mathrm{~km}$ southwest of the centre of the eddy (Fig. 1, Argo float 590659) observed the surface mixed layer extending to a depth of $220 \mathrm{~m}$ (Fig. 4A), with a salinity of 35.59 and a temperature of $20.1^{\circ} \mathrm{C}$. By 23 August the mixed layer had deepened to at least $275 \mathrm{~m}$ (Fig. 4B, 109 km north of the centre), entraining saltier water from below and increasing the salinity to 35.64 . The water at the core of the meander is significantly cooler than the EAC flowing around the edge of the meander (Fig. 3A).

The next available vertical profile within the eddy is from the shipboard CTD (Fig. 4C, $72 \mathrm{~km}$ north of the centre). A layer of warmer and fresher water $\sim 60 \mathrm{~m}$ deep that had been encircling the eddy has flowed radially towards the centre of the eddy and the original surface mixed layer has been submerged. This phenomenon has been previously observed in EAC WCEs (Cresswell, 1983; Tranter et al., 1982). The flooding creates a submerged layer, 200 $\mathrm{m}$ thick. Within the precision of measurement $( \pm 0.01)$, the salinity of the submerged layer remains at 35.65 over a 3 month period, as seen in the CTD profile (Fig. 4C), Argo float profiles (Fig. 4D) and during the glider deployment (Fig. 4E). Along the glider track from the 29 November - 8 December, covering a distance of $600 \mathrm{~km}$ and moving between the edge and centre of the eddy, the salinity of the submerged layer varied between 35.64 and 35.66 (Fig. 4E, grey lines below 100 m, Fig. 5). Out of contact with surface heat and freshwater fluxes, the submerged layer maintains a relatively constant temperature of $\sim 19.2^{\circ} \mathrm{C}$ and salinity of $\sim 35.65$.

The salinity observations of the separated eddy (Fig. 5) show a relatively constant depth $(60-100 \mathrm{~m})$ of the bottom of the low salinity surface layer across the eddy. This demonstrates that the flooding that began by encircling the eddy eventually spread relatively evenly across the eddy. The spring EAC water that flooded the eddy forms a new surface layer between 60 and $100 \mathrm{~m}$ 
deep with the original mixed layer lying beneath.

Remotely-sensed SST and sea-level elevation indicates the final injection of EAC water into the eddy ceased about the 3 December (not shown), as the eddy separated completely from the main EAC flow. On the 28-29 November, the Slocum glider sampled a fresh filament of EAC water that was part of the last injection of water into the WCE before separation from the EAC flow (Fig. 5, top $60 \mathrm{~m}, 100-230 \mathrm{~km}$ along transect, $\mathrm{S}<35.54$ ). The mooring array on the continental shelf off Sydney (Fig. 6) measured strong southward velocities (up to $1.25 \mathrm{~m} \mathrm{~s}^{-1}$ at the surface) of $19-22^{\circ} \mathrm{C}$ water from the 25 November until the 3 December (Fig. 6B). Further evidence of a filament can be seen in the top $40-60 \mathrm{~m}$ at the $140 \mathrm{~m}$ isobath (Fig. $6 \mathrm{C}$ ) as indicated by $>20^{\circ} \mathrm{C}$ waters. The inshore mooring (Fig. 6A) has cooler surface temperatures and only moderate southward velocities that suggest the water flowing past it was not entrained into the eddy.

The glider observations of the final EAC filament to flood the eddy (with $S<35.55$ ) give a filament depth of 60-80 m, which approximately corresponds to the depth of the $-0.5 \mathrm{~m} \mathrm{~s}^{-1}$ contour at the SYD100 mooring (Fig. 6). The width of the $S<35.55$ filament perpendicular to the flow at $33^{\circ} \mathrm{S}$ is $\sim 25 \mathrm{~km}$ (based on a $1 \mathrm{~km}$ MODIS SST image on the 28 November, not shown).

\subsection{Physical characteristics of the separated eddy}

The eddy separated on approximately the 3 December and by the 13 December was an isolated water mass that could be defined by surface temperatures above $20^{\circ} \mathrm{C}$, positive sea-level elevation anomaly and surface chlorophyll $a$ concentration $<0.25 \mathrm{mg} \mathrm{m}^{-3}$ (Fig. 3C \& Fig. 7C). The surface area of the eddy can be approximated assuming an elliptical shape. On the 13 December, $\sim 10$ days after the final injection of EAC water, the eddy had major and 
minor axes of lengths of $\sim 232$ and $\sim 196 \mathrm{~km}$ (Fig. 7C), giving a surface area of $143 \times 10^{9} \mathrm{~m}^{2}$.

The time to complete 1 lap of the eddy can be estimated by three methods. On 30 November, the curl of the surface velocity field calculated from geostrophic flow of the observed sea-level elevation is $\sim 1.6 \mathrm{rad} \mathrm{d}^{-1}$, so the time to complete a revolution is 7.9 days. Lagrangian paths calculated using a stationary velocity field suggest that close to the centre of the eddy it takes 6 days to return to the same geographical location. Thirdly, a regression of tangential speed versus radial distance gives a period of 8.4 days. For the glider moving along a 0-200 $\mathrm{m}$ depth undulating path with relative glider velocity primarily in a tangential direction, the time to make one rotation (return to the same geographical location) was 7.0 days.

\subsection{Biogeochemical properties}

Surface chlorophyll a concentrations of the eddy throughout the study period were low (Fig. 7). During formation, surface chlorophyll $a$ concentration at the eddy centre was $0.2 \mathrm{mg} \mathrm{m}^{-3}$ (Fig. 7A). Outside the eddy to the southwest concentrations exceeded $1 \mathrm{mg} \mathrm{m}^{-3}$. The mean spring surface chlorophyll $a$ concentration in the western Tasman Sea varies between 0.2 and $0.5 \mathrm{mg} \mathrm{m}^{-3}$ (Condie and Dunn, 2006). Surface filaments of up to $0.4 \mathrm{mg} \mathrm{m}^{-3}$ occurred in the EAC waters that flooded the eddy in September (Fig. 7A). Calculated geostrophic currents (Fig. 3A) suggest this high chlorophyll water was likely to have been advected northeast out of the eddy rather than retained in the eddy after separation.

The CTD station on the 14 October, $72 \mathrm{~km}$ north of the eddy centre, was undertaken 50 days before eddy separation, and was the first vertical profile in the eddy after flooding began (Fig. 4C). The flooding was complicated as 
shown by two layers of lower salinity water near the surface (0-25 m: 35.38; 25-100 m: 35.6). Nonetheless, a submerged layer with a salinity of 35.65 was present from 100-250 m.

Nitrate concentration at the CTD station was undetectable in the low-salinity surface waters that were flooding the eddy (not shown), suggesting nutrientlimited phytoplankton growth (Hassler et al., in press). At a depth of $148 \mathrm{~m}$, in the submerged layer, nitrate concentration was $1.7 \mathrm{mmol} \mathrm{m}^{-3}$. This is a comparatively low but non-zero concentration (stations outside the eddy at $150 \mathrm{~m}$ had concentrations of $\sim 7 \mathrm{mmol} \mathrm{m}^{-3}$ ).

Vertical profiles of dissolved oxygen show concentrations reached $20 \%$ above saturation in both the surface and submerged layers (Fig. 8). These are very high values, but appear to be confirmed based on the titration of bottle samples (see Discussion for more analysis). The concentration of oxygen roughly varied with fluorescence through the depth of the CTD cast (Fig. 8).

Shortly before separation (Fig. 7B), surface chlorophyll $a$ concentration varied between $0.1-0.5 \mathrm{mg} \mathrm{m}^{-3}$. To the northeast of the centre $\left(35^{\circ} 20^{\prime} \mathrm{S}, 153^{\circ} 00^{\prime} \mathrm{E}\right)$ and along the shelfbreak to the west $\left(34^{\circ} 40^{\prime} \mathrm{S}, 151^{\circ} 15^{\prime} \mathrm{E}\right)$ concentrations of up to $0.5 \mathrm{mg} \mathrm{m}^{-3}$ occurred along flow streamlines, suggesting injections of EAC water at this late stage of formation had an influence through either entrainment or stimulating phytoplankton growth within the eddy. In particular, the 10-20 km wide, $60 \mathrm{~m}$ deep filament of fresh EAC water at the shelfbreak sampled by the glider on the 28 November (Fig. 5) contained up to $1.5 \mathrm{mg} \mathrm{m}^{-3}$ (Fig. 9).

Ten days after separation surface chlorophyll a concentration clearly distinguished eddy water from that outside the eddy (Fig. 7C). At the centre of the eddy chlorophyll a concentrations were at their lowest $\left(0.1 \mathrm{mg} \mathrm{m}^{-3}\right)$. On the edge, particularly to the east at the interface with an adjacent cold-core eddy, surface concentrations reached $0.8 \mathrm{mg} \mathrm{m}^{-3}$. By early 2009 the surface 
chlorophyll $a$ concentrations in the eddy were similar to the surrounding water (Fig. 7D). The eddy itself was still a distinct feature with sea-level elevation and temperature anomalies of $0.5 \mathrm{~m}$ and $2{ }^{\circ} \mathrm{C}$ relative to the surrounding waters (Fig. 3D). Both eddy and surrounding waters had low surface chlorophyll a concentrations consistent with a mid-summer minimum typical for the region. The surface characteristics of the eddy from October 2008-January 2009 conform to the view that EAC WCEs are unproductive islands of tropical waters advected south into the western Tasman Sea.

A sub-surface maximum for chlorophyll $a$ concentration with values up to 2 $\mathrm{mg} \mathrm{m}^{-3}$ was evident along the glider transect (Fig. 9). Within the eddy the sub-surface chlorophyll maximum was found in the pycnocline formed at the interface of the surface and submerged layers. The pcynocline was found at a depth of between $50 \mathrm{~m}$ and $100 \mathrm{~m}$, with a thickness of 20-40 m. The closest the glider came to the centre was on the 2-3 December (Fig. 2) during which time the sub-surface maximum lifted from 85 to $60 \mathrm{~m}$. It is difficult to determine whether this relatively small depth change was a product of the formation of the eddy, a local (in time and/or space) instability such as internal waves, or vertical velocities at the centre. In any case, variations in surface mixed layer depth near the centre were no bigger than those in the rest of the eddy (Fig. 9).

Dissolved oxygen in the surface and submerged layers in late November (Fig. 10B) was significantly less than it was in mid October (Fig. 8). Coloured dissolved organic matter (CDOM) inferred from fluorescence was low in the eddy surface mixed layer (Fig. 10A) presumably due to photo-oxidation of CDOM to optically inactive forms of DOC (Oubelkheir et al., 2005; Niewiadomska et al., 2008; Nelson et al., 2010). In the low light levels of the submerged layer where photo-oxidation is limited, CDOM concentration was elevated. In the pycnocline where there was elevated chlorophyll $a$ concentration, oxygen was less than saturated, but higher than in the submerged layer. 


\section{Discussion}

The phenomenon of less dense water flowing over the top of a WCE has been described for a number of boundary current systems, and been referred to using terms such as submerging (Jeffrey and Hallegraeff, 1987) and flooding (Tranter et al., 1982) in the Tasman Sea, overwashing (Hitchcock et al., 1985; Chapman and Nof, 1988) in the North Atlantic, overriding (Tomosada, 1978) in the North Pacific and surface injection (Dietze et al., 2009) in the eastern Indian Ocean. In each of these systems, the vertical transport associated with surface flooding represents, for a few weeks at a time, a significant sink of water for the boundary current.

\subsection{Rate of submergence}

The rate of submergence of the original surface mixed layer can be estimated from Argo profiles leading up to the separation of the eddy (Fig. 4D). No flooding had occurred on the 23 August (Fig. 4B), 102 days before the eddy separated. Flooding ceased when the eddy fully separated from the EAC flow. Assuming submergence of $70 \mathrm{~m}$ based on the average depth of the surface mixed layer along the glider transect, the submergence rate is $0.7 \mathrm{~m} \mathrm{~d}^{-1}$. Spread evenly across the eddy surface area of $143 \times 10^{9} \mathrm{~m}^{2}$ implies a vertical transport of $\sim 1.1 \mathrm{~Sv}$ for 100 days.

During some periods of flooding submergence may have been much quicker. The vertical profiles from Argo float 5900562 (Fig. 4D) show the bottom of the submerged layer dropped $80 \mathrm{~m}$ over 21 days, representing a submergence rate of $3.8 \mathrm{~m} \mathrm{~d}^{-1}$, and a vertical transport if averaged over the whole eddy of $\sim 6.3 \mathrm{~Sv}$. A vertical transport of between 1.1-6.3 Sv represents a significant fraction of the average October southward flow of the EAC of $30 \mathrm{~Sv}$ (Ridgway and Godfrey, 1997). 
The 1.1-6.3 Sv of submergence is driven by EAC flow. The depth of EAC filaments flowing over the WCE are 60-80 m. In order to achieve $5 \mathrm{~Sv}$ in a $70 \mathrm{~m}$ deep flow moving at $1 \mathrm{~m} \mathrm{~s}^{-1}$ requires a width of $71 \mathrm{~km}$. Such a broad filament is visible in Figs. 3A and B. Given the rate of transport, its warmth and freshness, the EAC has the potential to regularly submerge the cooler and saltier waters of the western Tasman Sea.

\subsection{Phytoplankton response to flooding.}

The phytoplankton response to flooding in the 2008 WCE studied in this paper can be contrasted with the response in the only previous carefullystudied flooded WCE off southeast Australia - Eddy J of 1979. Eddy J had a surface mixed layer depth during September of between 300-350 m (Tranter et al., 1982; Brandt et al., 1981). In October soon after flooding began, the pycnocline was at a depth of between $75-100 \mathrm{~m}$ on the perimeter, but only 25$50 \mathrm{~m}$ at the centre (Tranter et al., 1982). The submerged layer had a salinity of $35.71 \pm 0.01$ and a nitrate concentration of $\sim 1.3 \mathrm{mmol} \mathrm{N} \mathrm{m}^{-3}$ (Tranter et al., 1982). No evidence was found of elevated chlorophyll $a$ concentrations in the pycnocline or submerged layer. Instead the submerged layer was assumed to contain unused nutrients due to light limitation of phytoplankton growth (Tranter et al., 1982).

In the 2008 WCE of this study, the high resolution sampling by the Slocum glider revealed a deep chlorophyll maximum in the pycnocline. The concentration of chlorophyll $a$ reached $\sim 2 \mathrm{mg} \mathrm{m}^{-3}$, suggesting that the nutrients in the pycnocline were taken up by phytoplankton. What allowed phytoplankton in the 2008 WCE to form a sub-surface chlorophyll maximum when Eddy J did not?

The development of a chlorophyll maximum in the pycnocline depends on suf- 
ficient light levels to allow the elevated nutrients to be consumed. To consider light limitation of phytoplankton growth in a flooded WCE, both the light level integrated over the surface mixed layer, and light at a fixed depth need to be estimated (Fig. 11). Before flooding, phytoplankton are mixed throughout the surface mixed layer, and the light available for photosynthesis can be approximated as the depth-integrated light from the surface to the base of the mixed layer (Fig. 11, black contours). After flooding, the phytoplankton community that is trapped in the pyncocline remains at a fixed depth as density gradients prevents vertical movement (Fig. 11, grey contours).

Vertical profiles of temperature and salinity can be used to estimate the light history of the phytoplankton found in the pycnocline after flooding. Before separation, the surface layer of 1979 Eddy J was mixing to depths of 300+ $\mathrm{m}$, and the depth-integrated light levels were between 1.5-2.5 mol photon $\mathrm{m}^{-2}$ $\mathrm{d}^{-1}$ (Fig. 11, CTD228 and CTD241). After separation when the pcynocline lay between 75-100 m, the light at this depth was between 0.4-1.5 mol photon $\mathrm{m}^{-2} \mathrm{~d}^{-1}$ (Fig. 11, CTD283 and CTD293).

Before flooding, observations show the 2008 WCE had surface mixed layer depths of 220 and $275 \mathrm{~m}$ (Fig. 4A and B). The depth-integrated light level at these times was $\sim 1.5-2.5 \mathrm{~mol}$ photon $\mathrm{m}^{-2} \mathrm{~d}^{-1}$ (Fig. 11, shown as black symbols). Although there were no vertical profiles from the 2008 WCE in September, it is likely that the mixed layer would have been shallower than Eddy J at the same time of the year. After flooding, the pycnocline was between 60 100 m deep (Fig. 9). For three Argo float profiles, the shipboard CTD station and the glider transect, the light fixed at the depth of the pycnocline was 0.7-4 mol photon $\mathrm{m}^{-2} \mathrm{~d}^{-1}$ (Fig. 11, shown as grey symbols).

Due to a slightly shallower surface mixed layer before flooding, phytoplankton in the pycnocline of the 2008 WCE were exposed to slightly higher light intensities than Eddy J. Additionally, while flooding increased the available 
light for the phytoplankton in the pcynolcine of the $2008 \mathrm{WCE}$, it decreased light for the phytoplankton community in Eddy J.

The lowest light level in which light-limited phytoplankton growth exceeds respiration, following Sverdrup's critical depth hypothesis, has been estimated for the North Atlantic to be $\sim 1.3$ mol photon $\mathrm{m}^{-2} \mathrm{~d}^{-1}$ (Siegel et al., 2002). While light exposure for the phytoplankton communities in the pycnocline of the 2008 WCE only slightly exceeds Eddy J, it is above the threshold for a viable population.

For any surface mixed layer (not necessarily in an eddy), whether flooding increases the light available to the submerged phytoplankton community depends on the depth of the original mixed layer, the transparency of the flooding waters, and the depth to which community is submerged. The surface mixed layers of EAC WCEs have been known to extend to a depth of greater than $400 \mathrm{~m}$ (Tranter et al. (1982), Argo float 5900871 on 19 September 2009 at $35^{\circ} 28^{\prime} \mathrm{S}, 153^{\circ} 28^{\prime} \mathrm{E}$ ), and flooding layers of the relatively clear EAC can be less than $30 \mathrm{~m}$ deep (Fig. 4B, top layer). Surface flooding by EAC waters in the western Tasman Sea, a common occurrence, has the potential to increase light exposure of submerged phytoplankton populations and create deep chlorophyll maximum in the pycnocline and even top of the submerged layers.

\subsection{Remineralization in the submerged layer.}

The process of remineralization was not measured directly, but can be considered through calculations of changing oxygen concentration and CDOM concentration (Nelson et al., 2010). These calculations assume that the submerged layer is a distinct water mass between mid October and early December, and that the observations of oxygen concentration are sufficiently accurate to measure a change. The salinity of the submerged layer remained unchanged within 
measurement precision, demonstrating little mixing with the fresher water either above or below the layer (Fig. 4). The quoted accuracy of the different oxygen sensors is $5 \%$ or less (see Methods), while the observed change in oxygen between mid October and early December is up to $40 \%$.

The supersaturation of oxygen at the CTD station during the flooding is exceptionally high (Fig. 8), but within the range of observations globally (Garcia et al., 2006). The high oxygen concentrations may be explained by the recent release of light limitation of phytoplankton growth described above, which drew the nitrate levels to below the detection limit in the surface (Hassler et al. (in press), Table 2). Atmospheric conditions were also calm leading up to the measurements, suggesting a relatively low air-sea flux of oxygen. However, the concentration of chlorophyll $a$ was only $0.12 \pm 0.00 \mathrm{mg} \mathrm{m}^{-3}$ at the surface, and $0.19 \pm 0.17 \mathrm{mg} \mathrm{m}^{-3}$ at $70 \mathrm{~m}$ (Hassler et al. (in press), Table 2). Some doubt remains as to whether this phytoplankton biomass is capable of super-saturating the surface and submerged layer by $20 \%$. Nonetheless, with both sensor and bottle samples confirming this level of oxygen saturation, calculations of oxygen change are based on a $20 \%$ supersatured state in mid October.

The light levels for most of the submerged layer will be below 1.3 mol photon $\mathrm{m}^{-2} \mathrm{~d}^{-1}$ (Fig. 11), in a light zone in which respiration is expected to exceed production (Siegel et al., 2002). Soon after the layer was submerged, the dissolved oxygen concentrations in the submerged layer were between 5-5.3 ml $\mathrm{L}^{-1}$ (Fig. 8). After separation, 50-60 days later, the oxygen concentration in the submerged layer varied between 4-4.6 $\mathrm{ml} \mathrm{L}^{-1}$ (Fig. 10B), a consumption of $\sim 1 \mathrm{ml} \mathrm{L}^{-1}$. This corresponds to the respiration of $1.0 \mathrm{ml} \mathrm{L}^{-1} \times 1000 \mathrm{~L} \mathrm{~m}^{-3}$ $\times 1.42 \mathrm{mg} \mathrm{O} \mathrm{Om}^{-1} \times 1 / 32 \mathrm{mmol} \mathrm{O}_{2}\left(\mathrm{mg} \mathrm{O}_{2}\right)^{-1} \times 16 / 138 \mathrm{mmol} \mathrm{N}(\mathrm{mmol}$ $\left.\mathrm{O}_{2}\right)^{-1}=5.15 \mathrm{mmol} \mathrm{N} \mathrm{m}{ }^{-3}$.

The respiration of a significant quantity of organic matter is consistent with the 
elevated CDOM fluorescence measured in early December. In a similar flooded WCE (Eddy Mario of 1982), Jeffrey and Hallegraeff (1987) found detrital pigments, identified from chromatography and spectral curve analysis, were dominant below $100 \mathrm{~m}$ depth, particularly in the top of the two isothermal layers. The increase in CDOM with oxygen depletion in the WCE is a trend seen on a basin scale with increases in CDOM with apparent oxygen utilization (AOU) in the Pacific and Indian Oceans (Nelson et al., 2010).

\subsection{Eddy mass and carbon budget}

As a result of their large size, occurrence a few times a year and generally southward migration, EAC WCEs play a significant role in both the mass and carbon budgets of the western Tasman Sea. For a submerged layer $\sim 200 \mathrm{~m}$ thick, the volume of water transport from surface contact to below the mixed layer during the formation of the eddy is $\sim 28 \times 10^{12} \mathrm{~m}^{3}$. Using the calculation of respired oxygen above with a C:O $\mathrm{O}_{2}$ ratio of 106/138 (Kirk, 1994), $\sim 0.4$ g C $\mathrm{m}^{-3}$ of organic carbon was sequestered in the layer, for a total of sequestered organic carbon in the submerged layer of $200 \mathrm{~m} \times 143 \times 10^{9} \mathrm{~m}^{2} \times 0.4 \mathrm{~g} \mathrm{C}$ $\mathrm{m}^{-3}$, or $11.4 \times 10^{12} \mathrm{~g} \mathrm{C}$.

The downward transport within the eddy must be accompanied by upward transport in the surrounding ocean. An analytical modelling study of the sinking of an idealised Gulf Stream ring suggests that the water within the submerged layer spirals out of the centre of the eddy at depth, and can even be entrained into the surface flooding (Chapman and Nof, 1988). Low salinity (Fig. 5) and oxygen (Fig. 10B) water to the north of the eddy $(900 \mathrm{~km}$ along the transect) indicates that the submergence drives upwelling around the edges of the eddy, although entrainment into the flooding waters is not seen. The high CDOM and presumably DIC concentrations of the upwelled water illustrate that the net fluxes associated with the submergence may be 
offset by upwelling. In any case, the Tasman Sea generally absorbs atmospheric $\mathrm{CO}_{2}$ (Takahashi et al., 2002; Macdonald et al., 2009), and the surface waters at the CTD station $\left(p \mathrm{CO}_{2}\right.$ of $\left.325 \mu \mathrm{atm}\right)$ were significantly below atmospheric. Furthermore, model simulations suggest upwelled waters in the Tasman Sea rarely outgas (Macdonald et al., 2009). So vertical transport associated with submerged layers is likely to increase regional oceanic carbon absorption.

\subsection{Capped WCEs.}

As mentioned in the introduction, EAC WCEs can have high surface productivity. Tranter et al. (1980) sampled a WCE off southeast Australia in mid September and mid November 1978 (Fig. 12). In September, the mixed layer depth was $\sim 250 \mathrm{~m}$ (Fig. 12C), and the surface chlorophyll $a$ concentration was low. Two months later, a cap of $\sim 0.5^{\circ} \mathrm{C}$ warmer surface water formed due to solar heating (Fig. 12B), with decreased nitrate concentration (Fig. 12B) and elevated phytoplankton biomass. The elevated biomass is clear in the CZCS image of the 21 November 1978 (Fig. 12E).

An even more extreme event occurred at the same time of the year in 1997 (Fig. 12D, F). Fortuitously a geomagnetic field study in the region (Hitchman et al., 2000) sampled the eddy in September 1997. Like the early stages of the 1978 capped WCE sampled by Tranter et al. (1980), the 1997 eddy had a 230-270 m deep surface mixed layer with a nitrate concentration of $\sim 3 \mathrm{mmol}$ $\mathrm{N} \mathrm{m}^{-3}$ (Fig. 12A) and $<0.15 \mathrm{mg} \mathrm{m}^{-3}$ surface chlorophyll $a$ concentration (Fig. 12D). Two months later surface chlorophyll $a$ increased by an order of magnitude (Fig. 12F). The 1997 WCE produced the most dramatic contrast between surface chlorophyll $a$ concentration inside and outside an EAC WCE off southeast Australia in the satellite record (1978-1986, 1996-97, 1997-2009).

The process of surface capping is only biologically significant if flooding has 
not already submerged the winter mixed layer. The EAC in spring is both fresher and warmer than in winter. While the WCE remains attached to the main EAC flow, surface flooding is likely to occur and surface chlorophyll concentrations will be determined by the biogeochemical properties of the flooding waters.

\subsection{Summary}

A suite of observations of a surface flooded WCE off southeast Australia in late 2008 reveal that: (1) the vertical transport in surface flooded WCEs off southeast Australia can account for a sizeable fraction of the EAC transport during eddy formation; (2) surface flooding can ease light limitation of phytoplankton growth in the pycnocline and even top of a submerged winter mixed layer and result in a sub-surface chlorophyll maximum; (3) depth-integrated chlorophyll a concentration in flooded WCEs can be equal to those that have incurred surface capping, despite an order of magnitude less surface chloro-

phyll $a$. WCEs can have drastically different biological responses depending on whether, and to what depth, the winter mixed layer is submerged. Future observational and theoretical work should focus on the factors leading up to separation of WCEs that determine whether surface flooding occurs, and if so, to what depth it submerges the winter surface mixed layer.

\section{Acknowledgements}

Thank you to the many scientists who have contributed their time and know how to the development of the IMOS infrastructure which made this study possible. The Slocum glider preparation, communication and data processing was provided by the Australian National Facility for Ocean Gliders (ANFOG). The Sydney mooring array is part of the Australian National Moor- 
ings Network (ANMN). Argo float data was collected and made available by the International Argo Project and the national programs that contribute to it (http://www.argo.ucsd.edu, http://argo.jcommops.org). Argo is a pilot program of the Global Ocean Observing System, and is supported by Argo Australia. ANFOG, ANMN, SOOP and Argo Australia are facilities of the Integrated Marine Observing System (IMOS) - an initiative of the Australian Government being conducted as part of the National Collaborative Research

Infrastructure Strategy. The authors gratefully acknowledge the funding of ARC Discovery Project DP0880078 held by IS and MB and DP0557618 held by MB that funded the interpretation of the integrated observations. Thank you to the scientists and crew of the Southern Surveyor cruise (SS200810). Gridded sea-level anomaly and geostrophic currents (Fig. 3, 7 and 12) were produced by Madeleine Cahill of CSIRO and used in the navigation of the Slocum glider. Thank you to Richard Matear, George Cresswell and three anonymous reviewers for insightful comments.

\section{References}

Airey, D., 1983. Isothermal temperatures and transformations of the warmcore eddies in the western Tasman Sea. Aust. J. Mar. Freshw. Res. 34, $681-685$.

Baird, M. E., Timko, P. G., Wu, L., 2007. The effect of packaging of chlorophyll within phytoplankton and light scattering in a coupled physical-biological ocean model. Mar. Fresh. Res. 58, 966-981.

Bakun, A., 2006. Fronts and eddies as key structures in the habitat of marine fish larvae: opportunity, adaptive response and competitive advantage. Scientia Marina 70S2, 105-122.

Behrenfeld, M. J., Boss, E., 2006. Beam attenuation and chlorophyll concentration as alternative optical indices of phytoplankton biomass. J. Mar. Res. 64, 431-451. 
Brandt, S. B., Parker, R. R., Vaudrey, D. J., 1981. Physical and biological description of warm-core eddy J during September-October 1979. Tech. rep., Report Number 126, Division of Fisheries and Oceanography, CSIRO.

Brassington, G. B., Summons, N., Lumpkin, R., in press. Observed and simulated Lagrangian and eddy dynamical processes of the East Australian Current and Tasman Sea. Deep Sea Res. II .

Brock, T. D., 1981. Calculating solar radiation for ecological studies. Ecol. Modelling 14, 1-19.

Chapman, R., Nof, D., 1988. The sinking of warm-core rings. J. Phys. Oceanogr. 18, 565-583.

Condie, S. A., Dunn, J. R., 2006. Seasonal characteristics of the surface mixed layer in the Australasian region: implications for primary production regimes and biogeography. Mar. Freshwater Res. 57, 569-590.

Cowley, R., Critchley, G., Eriksen, R., Latham, V., Plaschke, R., Rayner, M., Terhell, D., 1999. CSIRO Marine Laboratories Report 236: Hydrochemistry Operations Manual. Tech. rep., CSIRO Marine Laboratories, Hobart.

Cresswell, G. R., 1982. The coalescence of two East Australian Current warmcore eddies. Science 215, 161-4.

Cresswell, G. R., 1983. Physical evolution of Tasman Sea Eddy J. Aust. J. Mar. Freshw. Res. 34, 495-513.

Cresswell, G. R., Legeckis, R., 1986. Eddies off southeastern Australia. DeepSea Res. 33, 1527-1562.

Deng, X., Griffin, D., Ridgway, K., Church, J., Featherstone, W., White, N., Cahill, M., 2010. Satellite altimetry for geodetic, oceanographic and climate studies in the Australian region. In: Vignudelli, S., Kostianoy, A. G., Cipollini, P., Benveniste, J. (Eds.), Coastal Altimetry. Springer, Berlin.

Dietze, H., Matear, R., Moore, T., 2009. Nutrient supply to anticyclonic mesoscale eddies off western Australia estimated with artificial tracers released in a circulation model. Deep Sea Res. I 56, 1440-1448.

Falkowski, P. G., Kolber, Z., 1995. Variations in chlorophyll fluorescence yields 
in phytoplankton in the world oceans. Aust. J. Plant. Physiol. 22, 341-55.

Franks, P., Wroblewski, J., Flierl, G., 1986. Prediction of phytoplankton growth in response to the frictional decay of a warm-core ring. J. Geophys. Res. 91, C6.

Garcia, H. E., Locarnini, R. A., Boyer, T. P., Antonov, J. I., 2006. World Ocean Atlas 2005, Volume 3: Dissolved Oxygen, Apparent Oxygen Utilization, and Oxygen Saturation. Tech. rep., S. Levitus, Ed. NOAA Atlas NESDIS 63, U.S. Government Printing Office, Washington, D.C., 342 pp.

Griffiths, F. B., Wadley, V. A., 1986. A synopitic comparison of fishes and crustaceans from a warm-core eddy, the East Australian Current, the Coral Sea and the Tasman Sea. Deep-Sea Res. 33, 1907-1922.

Hamon, B. V., 1965. The East Australian current, 1960-64. Deep Sea. Res. $12,899-921$.

Hassler, C. S., Djajadikarta, J. R., Doblin, M. A., Everett, J. D., Thompson, P. A., in press. Characteristion of water masses and phytoplankton nutrient limitation in the East Australian Current separation zone during spring 2008. Deep Sea Res. II .

Hitchcock, G. L., Langdon, C., Smayda, T. J., 1985. Seasonal variations in the phytoplankton biomass and productivity of a warm-core Gulf Stream ring. Deep Sea Res. 32, 1287-1300.

Hitchman, A. P., Milligan, P. R., Lilley, F. E. M., White, A., Heinson, G. S., 2000. The total-field geomagnetic coast effect: The CICADA97 line from deep Tasman Sea to inland New South Wales. Exploration Geophys. 31, $52-57$.

Jeffrey, S. W., Hallegraeff, G. M., 1980. Studies of phytoplankton species and photosynthetic pigments in a warm core eddy of the East Australian Current. I. Summer populations. Mar. Ecol. Prog. Ser. 3, 285-294.

Jeffrey, S. W., Hallegraeff, G. M., 1987. Phytoplankton pigments, species and light climate in a complex warm-core eddy of the East Australian Current. Deep-Sea Res. 34, 649-673. 
Kalnay, E., Kanamitsu, M., Kistler, R., Collins, W., Deaven, D., Gandin, L., Iredell, M., Saha, S., White, G., Woollen, J., Zhu, Y., Chelliah, M., Ebisuzaki, W., Higgins, W., Janowiak, J., Mo, K., Ropelewski, C., Wang, J., Leetmaa, A., R., R., R., J., Joseph, D., 1996. The ncep/ncar 40-year reanalysis project. Bulletin of the American Meteorological Society 77, 437471.

Kirk, J. T. O., 1994. Light and Photosynthesis in Aquatic Ecosystems, 2nd Edition. Cambridge University Press, Cambridge.

Macdonald, H. S., Baird, M. E., Middleton, J. H., 2009. The effect of wind on continental shelf carbon fluxes off southeast Australia: a numerical model. J. Geophys. Res. 114, C05016,doi:10.1029/2008JC004946.

Mahadevan, A., Thomas, L. N., Tandon, A., 2008. Comment on "eddy/wind interactions stimulate extraordinary mid-ocean plankton blooms". Science $320,448 b$.

Mann, K. H., Lazier, J. R. N., 2006. Dynamics of Marine Ecosystems, 3rd Edition. Blackwell Scientific Publications Inc., Oxford.

Mata, M. M., Wijffels, S. E., Church, J. A., Tomczak, M., 2006. Eddy shedding and energy conversions in the East Australian Current. J. Geophys. Res. 111, C09034, doi:10.1029/2006JC003592.

Millero, F. J., Chen, C. T., Bradshaw, A., Schleicher, K., 1980. A new high pressure equation of state for seawater. Deep-Sea Res. 27A, 255-264.

Morison, J., Andersen, R., Larson, N., D’Asaro, E., , Boyd, T., 1994. The correction for thermal-lag effects in Sea-Bird CTD data. J. Atmos. Oceanic Technol. 11, 1151-1164.

Nelson, N. B., Siegel, D. A., Carlson, C. A., Swan, C. M., 2010. Tracing global biogeochemical cycles and meridional overturning circulation using chromophoric dissolved organic matter. Geophys. Res. Lett. 37, L03610, doi:10.1029/2009GL042325.

Niewiadomska, K., Claustre, H., Prieur, L., d' Ortenzio, F., 2008. Submesoscale physical-biogeochemical coupling across the Ligurian Current 
(northwestern Mediterranean) using a bio-optical glider. Limnol. Oceanogr. $53,2210-2225$.

Nilsson, C. S., Cresswell, G. R., 1981. The formation and evolution of warm core eddies. Prog. Oceanogr. 9, 133-183.

Oubelkheir, K., Claustre, H., Sciandra, A., Babin, M., 2005. Bio-optical and biogeochemical properties of different trophic regimes in oceanic waters. Limnol. Oceanogr. 50, 1795-1809.

Ridgway, K. R., Dunn, J. R., 2003. Mesoscale structure of the mean East Australian Current System and its relationship with topography. Prog. Oceanogr, 56, 189-222.

Ridgway, K. R., Godfrey, J. S., 1997. Seasonal cycle of the East Australian Current. J. Geophys. Res. 102, 921-936.

Sackmann, B. S., Perry, M. J., Eriksen, C. C., 2008. Seaglider observations of variability in daytime fluorescence quenching of chlorophyll-a in Northeastern Pacific coastal waters. Biogeosciences Discuss. 5, 2839-2865.

Scott, B. D., 1981. Hydrological structure and phytoplankton distribution in the region of a warm-core eddy in the Tasman Sea. Aust. J. Mar. Freshwater Res. 32, 479-92.

Siegel, D. A., Doney, S. C., Yoder, J. A., 2002. The North Atlantic spring phytoplankton bloom and Sverdrup's critical depth hypothesis. Science 296, 730-733.

Takahashi, T., Sutherland, S. C., Sweeney, C., Poisson, A., Metzl, N., Tilbrook, B., Bates, N., Wanninkhof, R., Feely, R. A., Sabine, C., et al., 2002. Global sea-air $\mathrm{CO}_{2}$ flux based on climatological surface ocean $p \mathrm{CO}_{2}$, and seasonal biological and temperature effects. Deep-Sea Res. II 49, 1601-1622.

Tomosada, A., 1978. A large warm eddy detached from the Kuroshio east of Japan. Bull. Tokai. Reg. Fish. Res. Lab. 94, 59-102.

Tranter, D. J., Carpenter, D. J., Leech, G. S., 1986. The coastal enrichment effect of the East Australian Current eddy field. Deep-Sea Res. 33, 17051728. 
Tranter, D. J., Leech, G. S., Airey, D., 1983. Edge enrichment in an ocean eddy. Aust. J. Mar. Freshwater Res. 34, 655-680.

Tranter, D. J., Leech, G. S., Vaudrey, D. J., 1982. Biological significance of surface flooding in warm-core ocean eddies. Nature 297, 572-574.

Tranter, D. J., Parker, R. R., Cresswell, G. R., 1980. Are warm-core eddies unproductive. Nature 284, 540-542.

Waite, A. M., Thompson, P. A., Pesant, S., Feng, M., Beckley, L. E., Domingues, C. M., Gaughan, D., Hanson, C. E., Holl, C. M., Koslow, T., Meuleners, M., Montoya, J. P., Moore, T., Muhling, B. A., Paterson, H., Rennie, S., Strzelecki, J., Twomey, L., 2007. The Leeuwin Current and its eddies: An introductory overview. Deep Sea Res. II 54, 789-796.

Weiss, R., 1970. The solubility of nitrogen, oxygen and argon in water and seawater. Deep Sea Res. 17, 721-735.

Wilkin, J. L., Zhang, W. G., 2007. Modes of mesoscale sea surface height and temperature variability in the East Australian Current. J. Geophys. Res. 112, C01013, doi:10.1029/2006JC003590.

Yoshimori, A., Kishi, M. J., 1994. Effects of interaction between two warm-core rings on phytoplankton distribution. Deep Sea Res. I 41, 1039-1052.

Young, J. W., 1989. The distribution of hyperiid amphipods (Crustacea:Peracarida) in relation to warm-core eddy $\mathrm{J}$ in the Tasman Sea. J. Plankton Res. 11, 711-728.

Young, J. W., Bradford, R., Lamb, T. D., Clementson, L. A., Kloser, R., Galea, H., 2001. Yellowfin tuna (Thunnus albacares) aggregations along the shelf break off south-eastern Australia: links between inshore and offshore processes. Mar. Freshwater Res. 52, 463-74. 


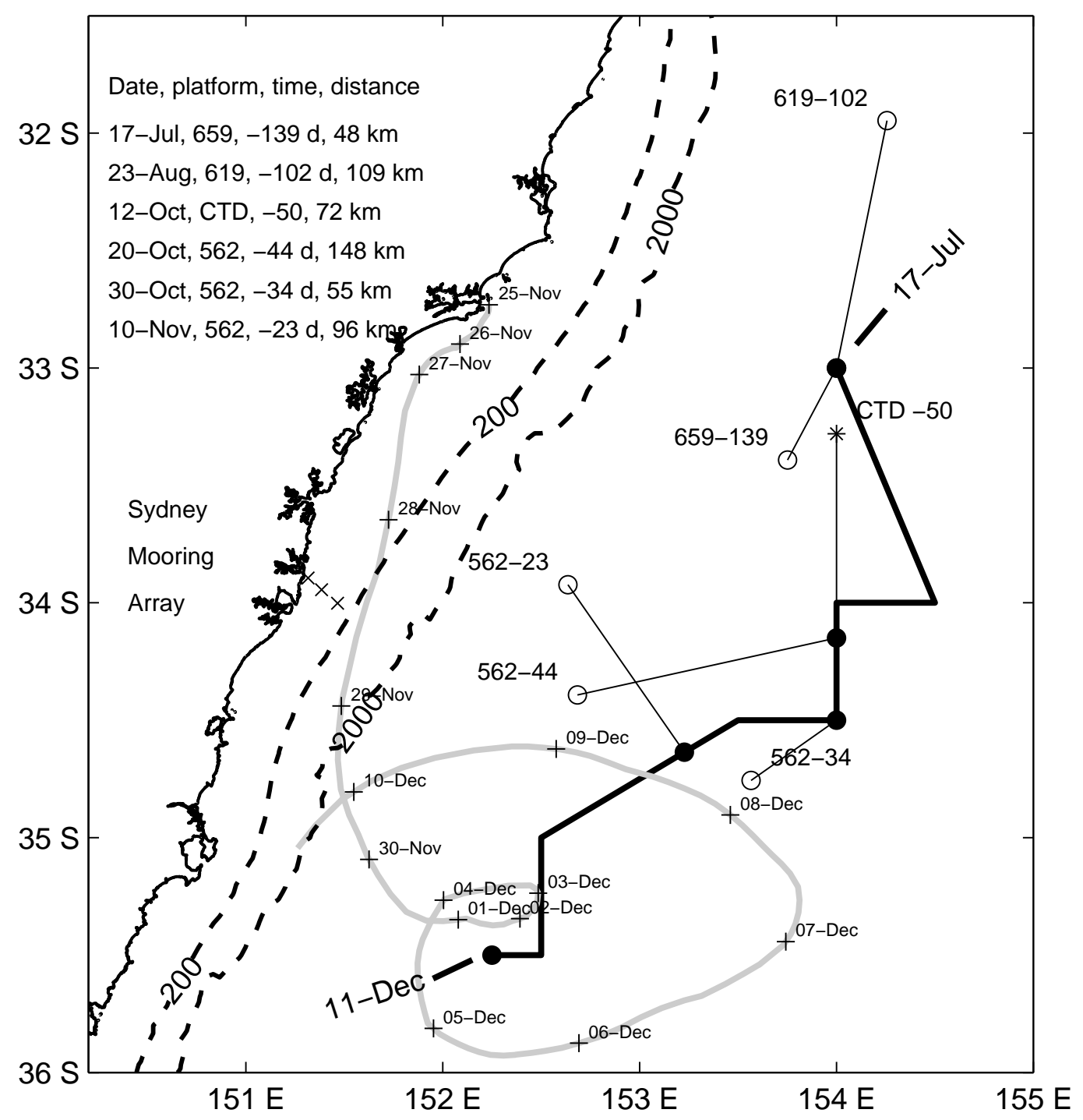

Fig. 1. Location of the centre of the WCE and in situ sampling sites. The centre of the eddy from 17 Jul - 11 Dec is shown as a thick black line. Locations of the CTD $(*)$ and Argo floats (o) are shown, with a thin black line joining the sampling location to the centre of the eddy at the sampling time. The profile of Argo float - XXX, YYY days before the eddy separated is denoted by XXX-YYY. The distance between in situ sampling locations and the eddy centre are given at the top left. Glider path is shown as a grey line with location marked by date at midday Australian Eastern Standard Time. The Sydney Mooring Array across the continental shelf at $\sim 34^{\circ} \mathrm{S}$ is shown a black $\times$. 


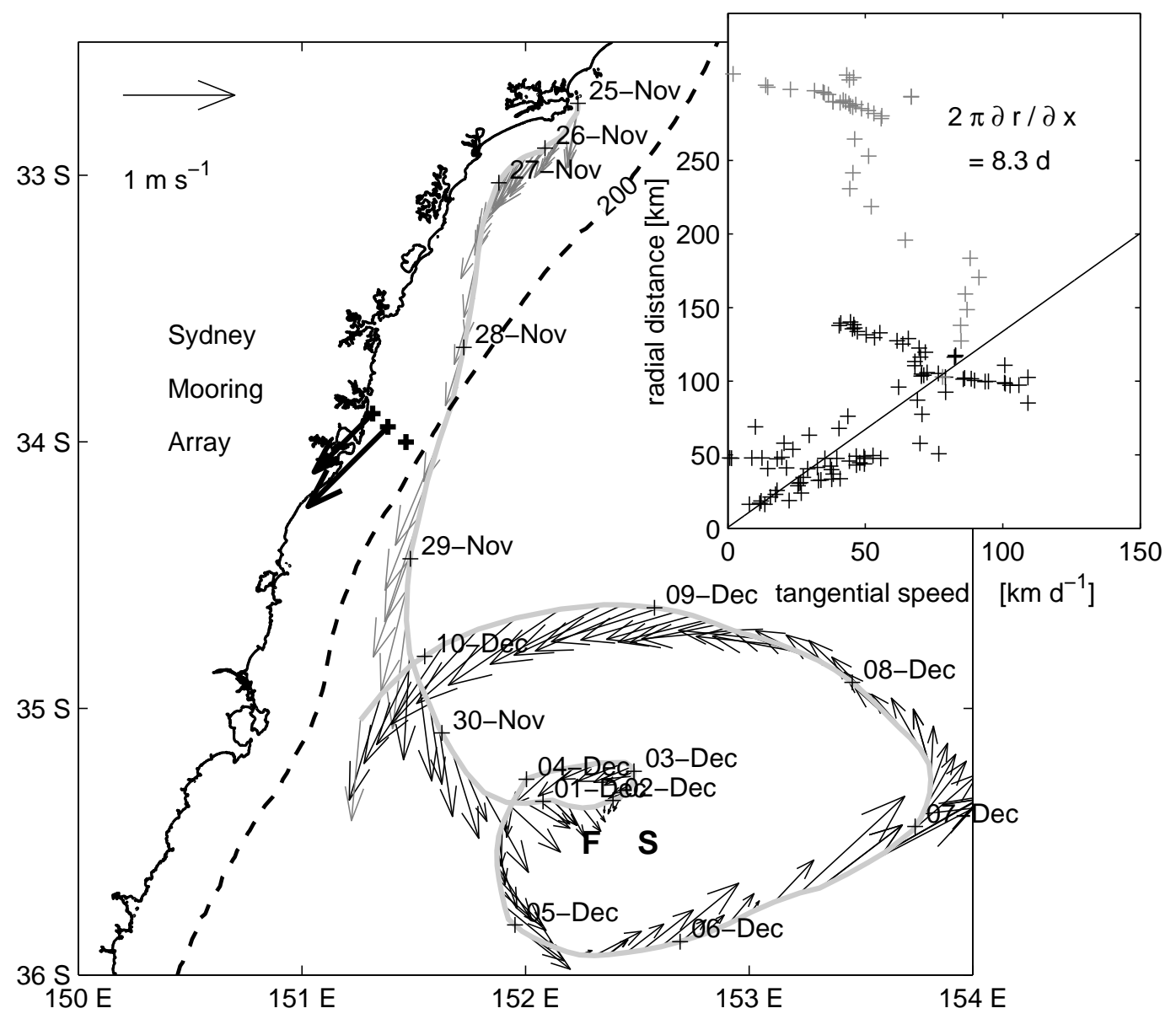

Fig. 2. Glider path (grey line) and glider-estimated depth-averaged velocity (arrows) relative to the (translating) eddy centre. Arrow shading indicates whether the local water is in the filament of EAC waters filling the eddy (grey) or within the eddy (black), based on current direction. The eddy centre calculated using altimetry on the 1 and 5 December is marked with a bold S and F. Insert: The distance from the centre of the eddy against relative tangential velocity for points identified on main figure. Again black indicates within the eddy. The fit of the line (forced through the origin) gives one estimate of the period of the eddy. Glider location is marked by date at midday Australian East Standard Time. The Sydney Mooring Array across continental shelf at $\sim 34^{\circ} \mathrm{S}$ with depth-averaged velocity for the 28 November is shown with thick black arrows. 

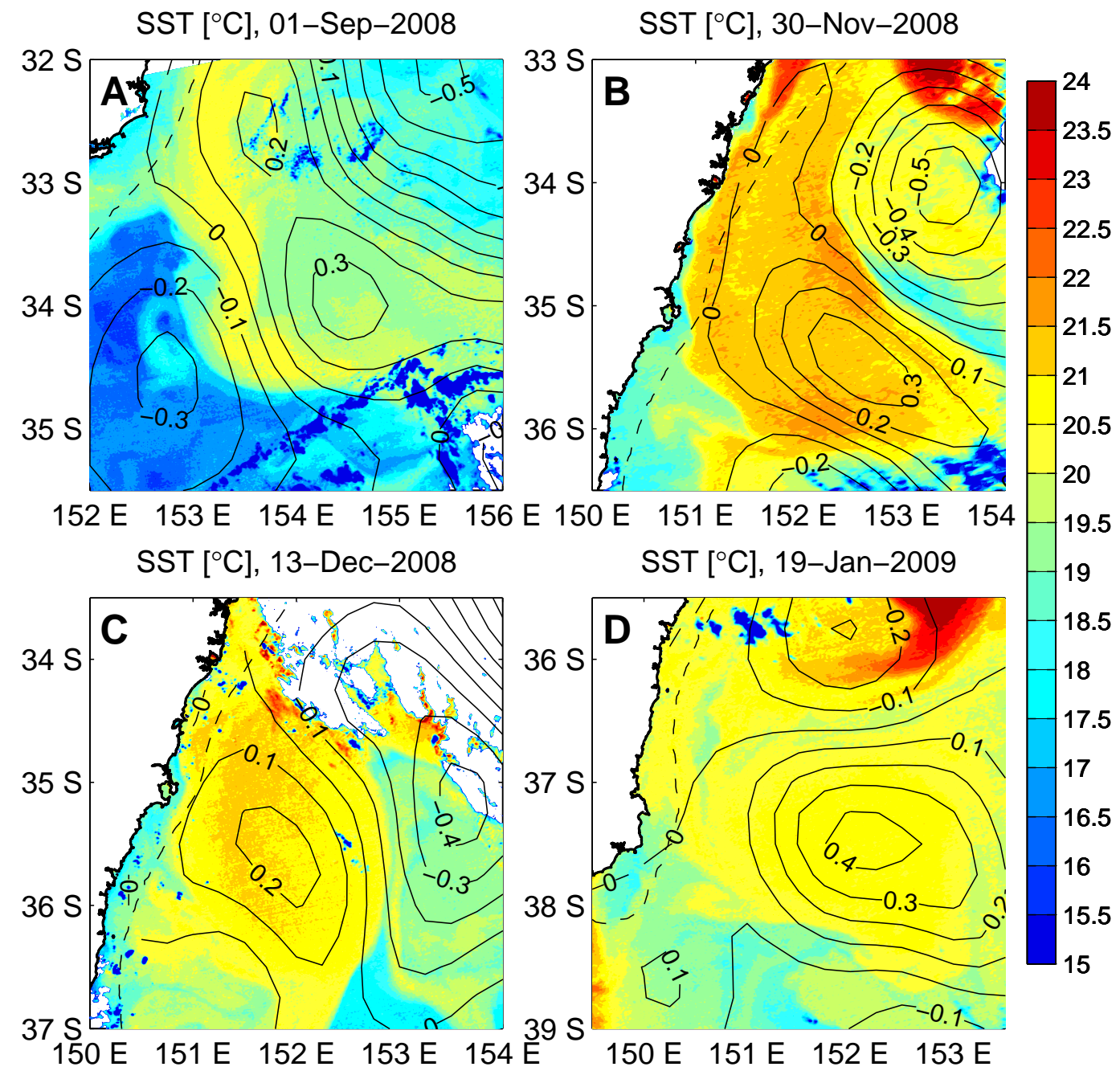

Fig. 3. Surface temperature (Aqua MODIS, Level 2) with tidal-residual, isostatically-adjusted sea-level anomaly using the Jason-1, Jason-2 and Envisat altimetry. The $200 \mathrm{~m}$ isobath is shown as a dashed black line. The Panels are (A) 93 days and (B) 3 days before eddy separation, and (C) 10 days and (D) 47 days after. The grey line on Panel $\mathrm{B}$ is the glider track, with its location at the time of image marked with a circle. 

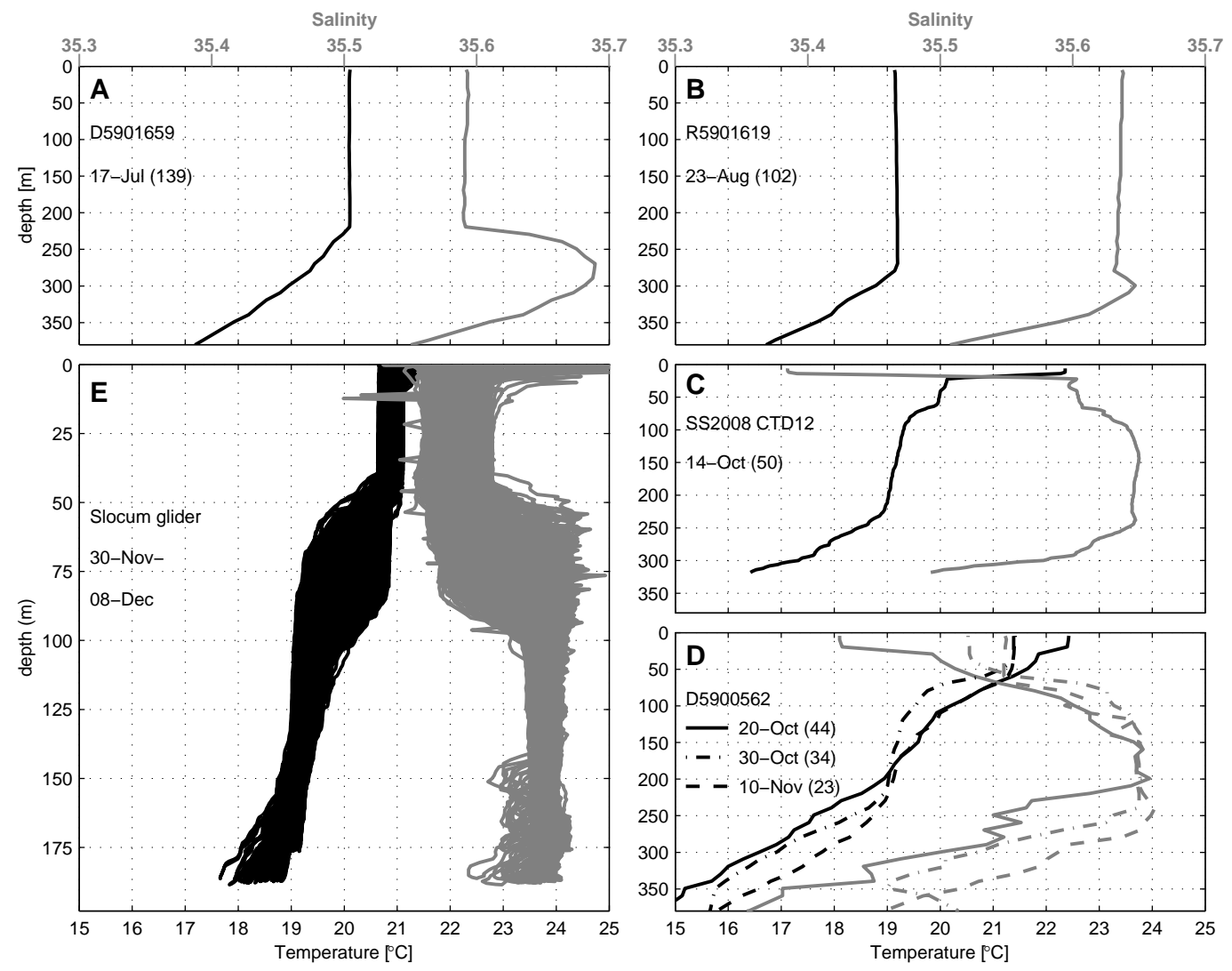

Fig. 4. Vertical profiles of temperature and salinity during the lifetime of the WCE. Colours show temperature (black, ${ }^{\circ} \mathrm{C}$ ) and salinity (grey). Chronological order is clockwise from the top left. Panels A, B and D show Argo profiles; Panel C shows RV Southern Surveyor (SS10/2008) CTD station 12 at $32^{\circ} 50^{\prime} \mathrm{S}, 154^{\circ} 00^{\prime} \mathrm{E}$ on the 14 October 2008 at 12:30 am AEST. Panel E shows profiles from the 30 November - 8 December when the Slocum glider was within the WCE. The location of the vertical profiles relative to the eddy centre is given in Fig. 1. 


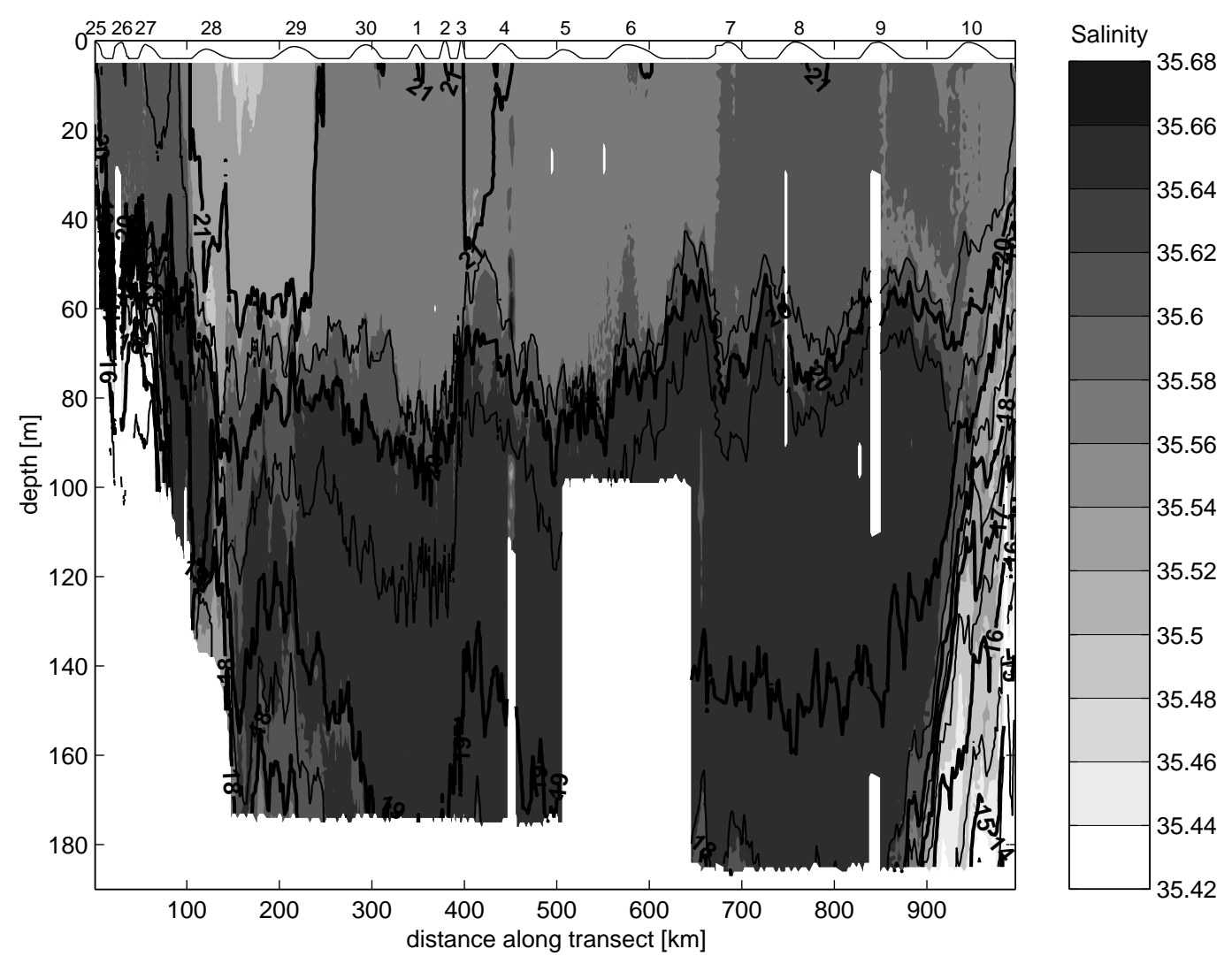

Fig. 5. Salinity calculated from conductivity along the entire glider path (Fig. 2) with a correction for the temperature lag of the conductivity sensor. The glider entered the eddy on 28 November, $100 \mathrm{~km}$ along the transect, and was retrieved from the near the edge on the 11 December. Clear sky irradiance is shown as a black line at the surface with the day of the month given above the noontime maximum. Solar irradiance is scaled by $200 \mathrm{~W} \mathrm{~m}^{-2}=1 \mathrm{~m}$, such that $4 \mathrm{~m}$ depth is zero and $0 \mathrm{~m}$ is $800 \mathrm{~W} \mathrm{~m}^{-2}$. Temperature contours are shown every $0.25^{\circ} \mathrm{C}$, with thickened integer contours that are labelled. 


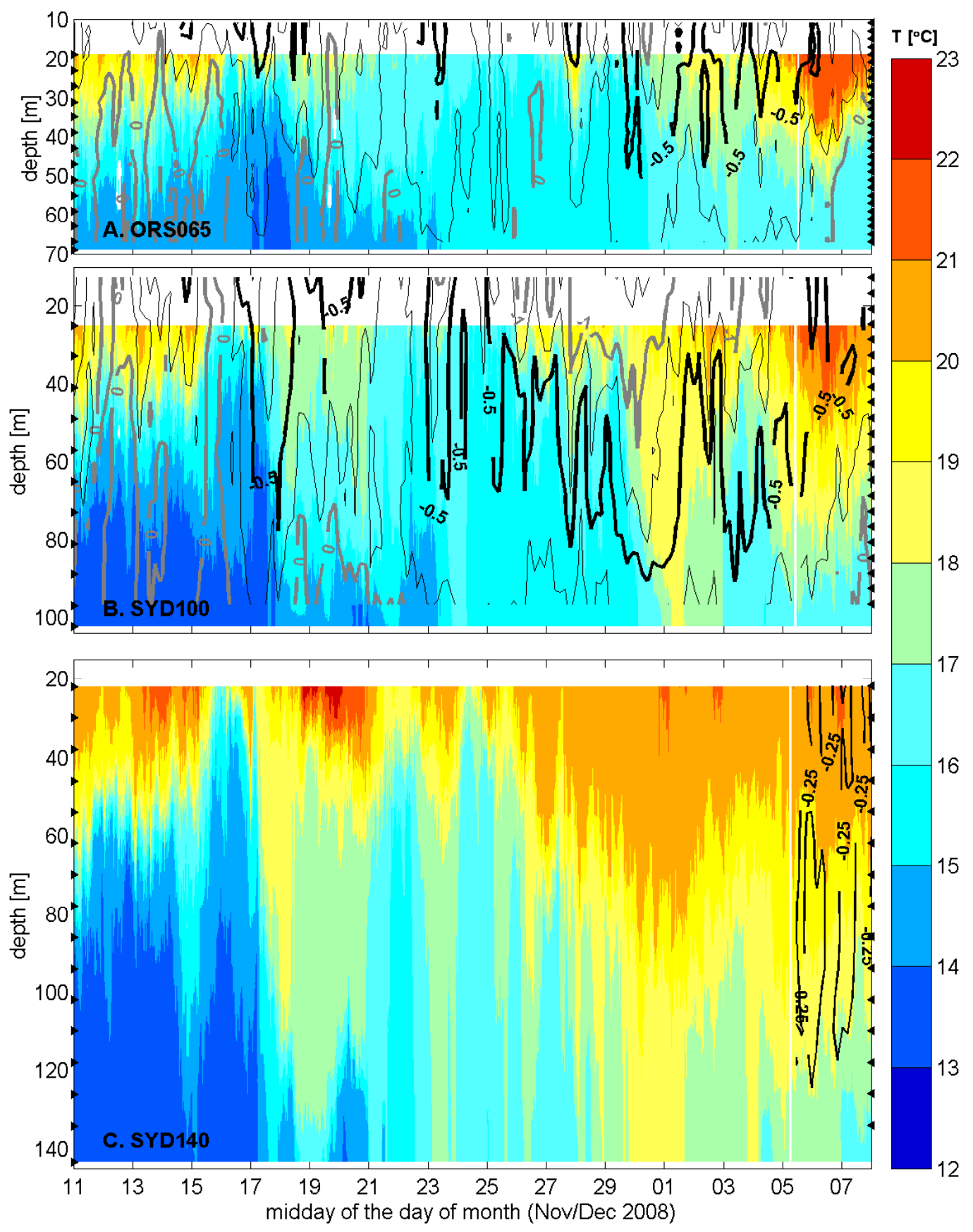

Fig. 6. Vertical profiles of temperature (shading) and north-south velocity (contours) from (A) ORS065 mooring at $33^{\circ} 54.40^{\prime} \mathrm{S}, 151^{\circ} 18.97^{\prime} \mathrm{E}$; (B) SYD100 mooring at $33^{\circ} 56.63^{\prime} \mathrm{S}, 151^{\circ} 23.03^{\prime} \mathrm{E}$; and (C) SYD140 mooring at $34^{\circ} 00.08^{\prime} \mathrm{S}, 151^{\circ} 27.92^{\prime} \mathrm{E}$ (see locations on Fig. 2). Velocity contours every $0.25 \mathrm{~m} \mathrm{~s}^{-1}$, north being positive, with $0,0.5$ and 1 labelled and bold (and -0.25 in C.). Black triangles on left indicate depth of the thermometers, and on the right centre of the ADCP depth bin. The ADCP record at SYD140 begins on 5 December. 


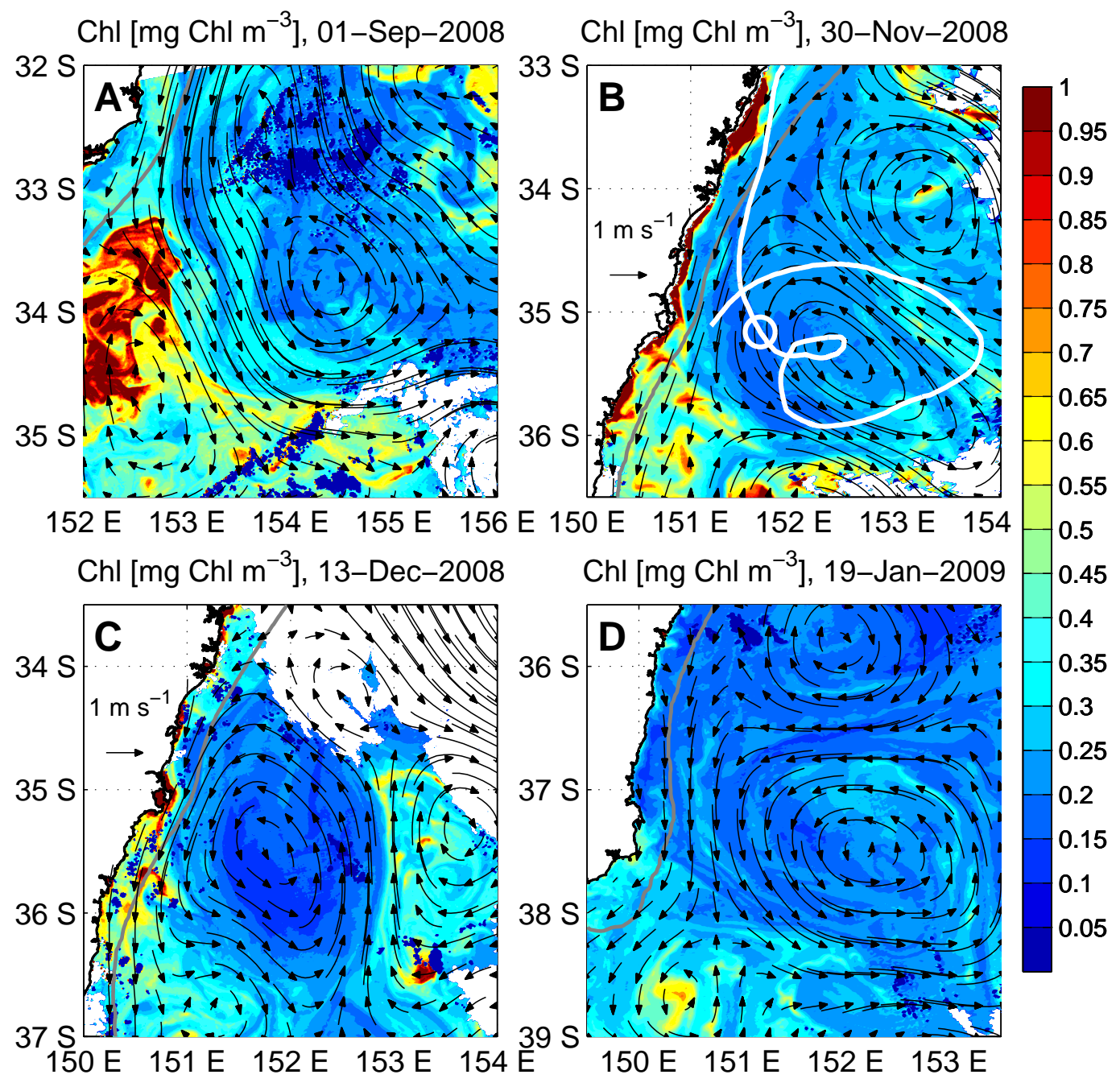

Fig. 7. Surface chlorophyll $a$ concentration (Aqua MODIS, Level 2) with geostrophic velocity calculated from sea-level anomaly shown in Fig. 3. Arrows represent Lagrangian paths for the 24 hours leading up to the midday satellite image. The 200 $\mathrm{m}$ isobath is shown as a grey line. The Panels are (A) 93 days, (B) 3 days before eddy separation with glider path shown as white and the glider location on the 30 November circled, (C) 10 days, and (D) 47 days after. 


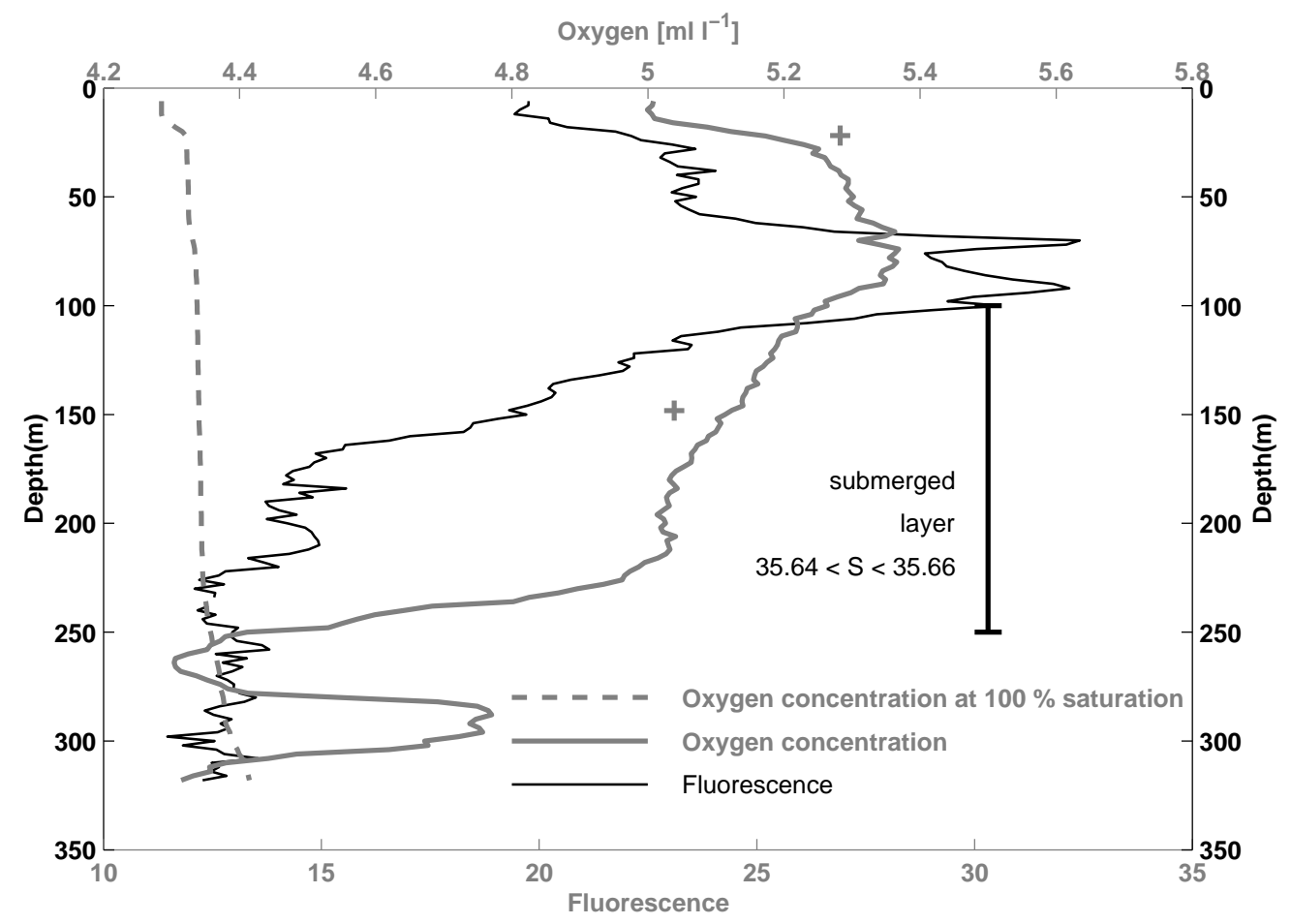

Fig. 8. Vertical profiles of oxygen concentration, concentration of oxygen at $100 \%$ saturation calculated from temperature and salinity (Weiss, 1970) and fluorescence from the CTD station 12 at $32^{\circ} 50^{\prime} \mathrm{S}, 154^{\circ} 00^{\prime} \mathrm{E}$ on the 14 October 2008 at 12:30 am AEST. At depths $21 \mathrm{~m}$ and $148 \mathrm{~m}$, oxygen concentration obtained from bottle samples is indicated by a grey cross. Temperature and salinity profiles for the same location are shown in Fig. 4C. The depth range of the submerged layer at the time is indicated with a thick line. The location of CTD station relative to the eddy centre is given in Fig. 1. 


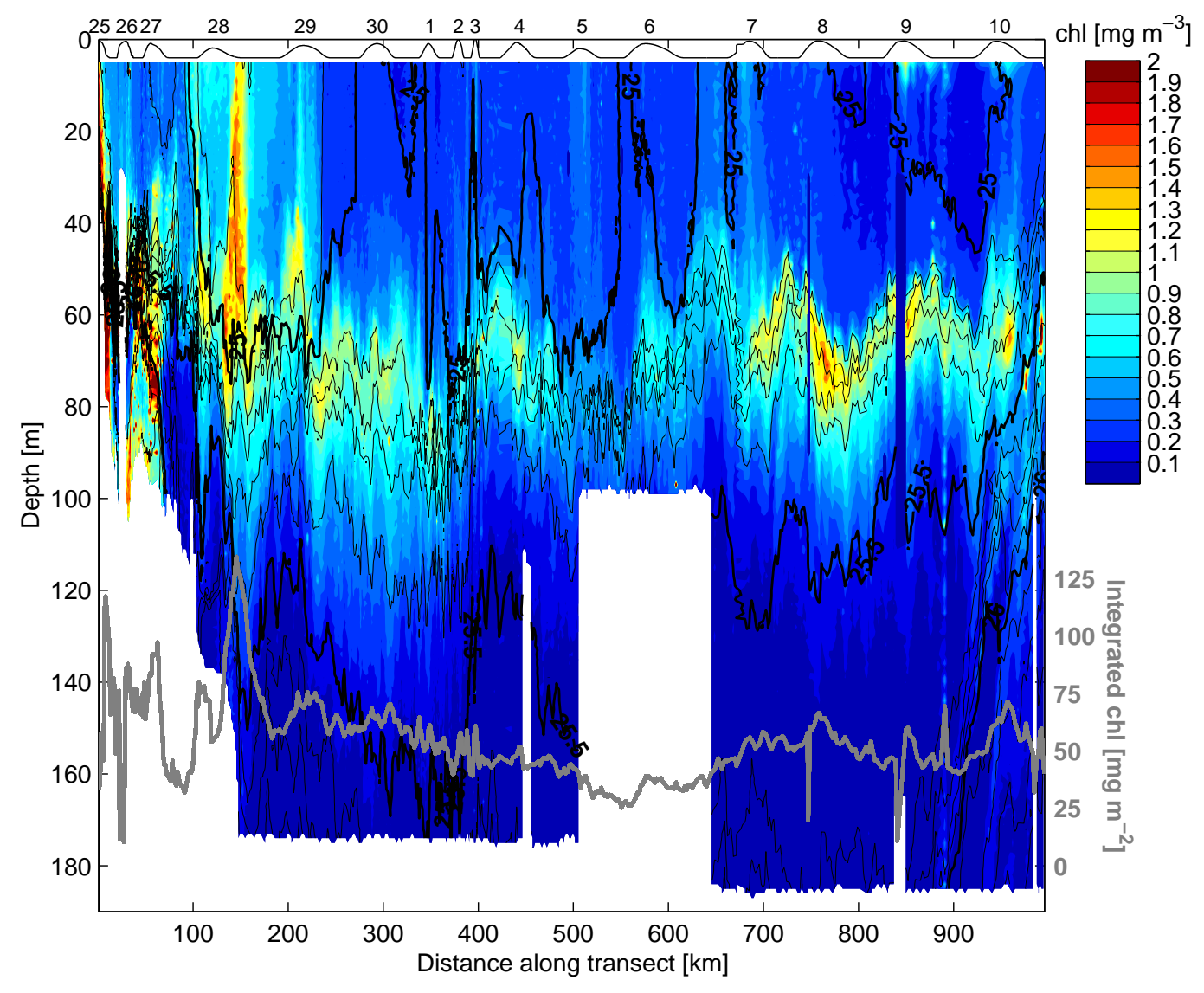

Fig. 9. Chlorophyll $a$ concentration along the glider transect (Fig. 2) calculated from fluorescence, corrected for non-photochemical quenching. Clear sky irradiance is shown as a black line at the surface with the day of the month given above the noontime maximum sun. Solar irradiance is scaled by $200 \mathrm{~W} \mathrm{~m}^{-2}=1 \mathrm{~m}$, such that $4 \mathrm{~m}$ depth is zero and $0 \mathrm{~m}$ is $800 \mathrm{~W} \mathrm{~m}^{-2}$. Potential density is calculated following Millero et al. (1980), with contours shown every $0.1 \mathrm{~kg} \mathrm{~m}^{-3}$, and 0.5 increments labelled and thickened. The grey line gives depth-integrated chlorophyll $a$ concentration (for the depth of the glider track). 


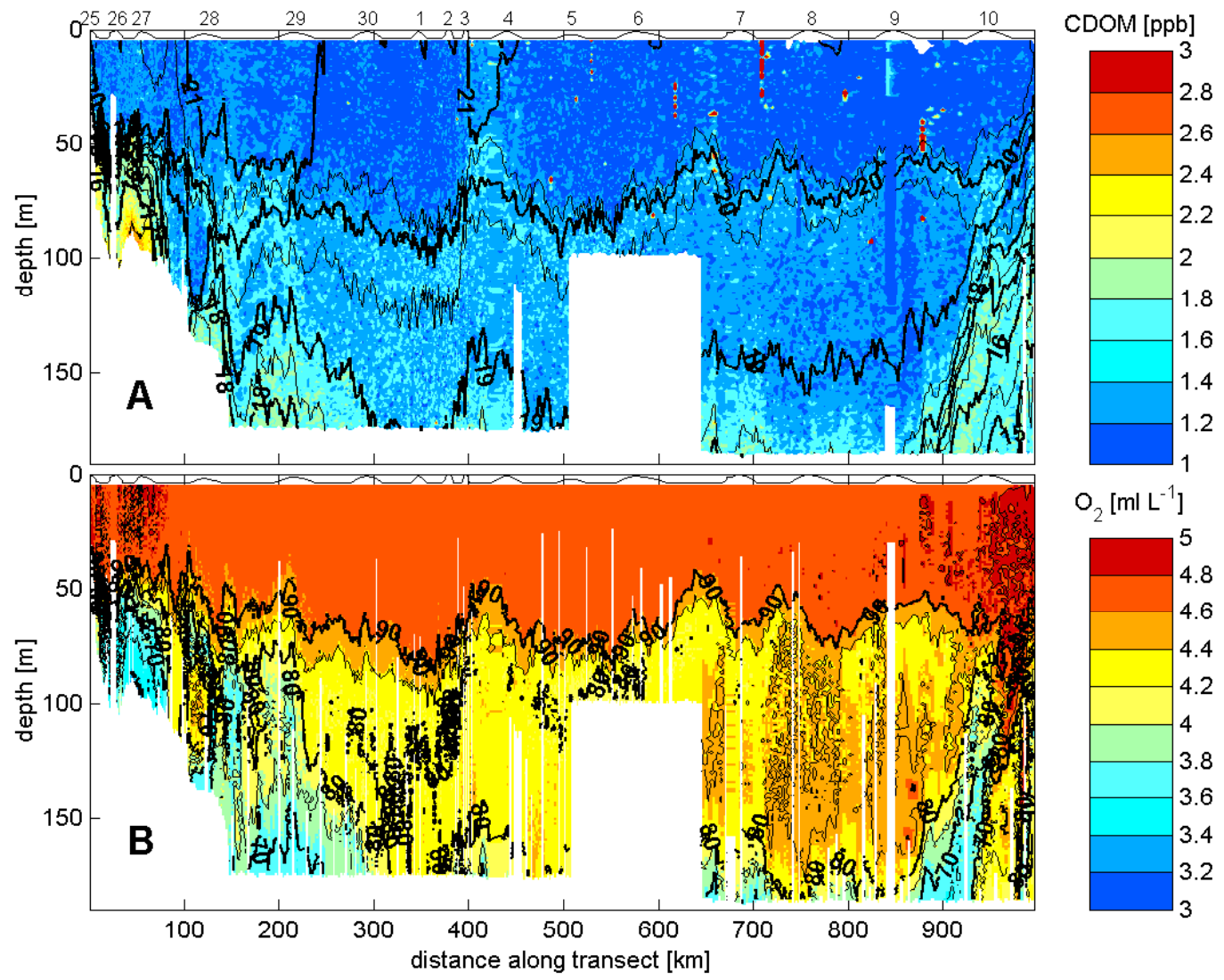

Fig. 10. Vertical profile along the glider transect of (A) coloured dissolved organic matter (ppb) determined from fluorescence with potential density contours $\left(\mathrm{kg} \mathrm{m}^{-3}\right)$ and $(\mathrm{B})$ dissolved oxygen $\left(\mathrm{ml} \mathrm{L}^{-1}\right)$ with oxygen saturation (percentage) contours (Weiss, 1970). For more details see Fig. 9. 


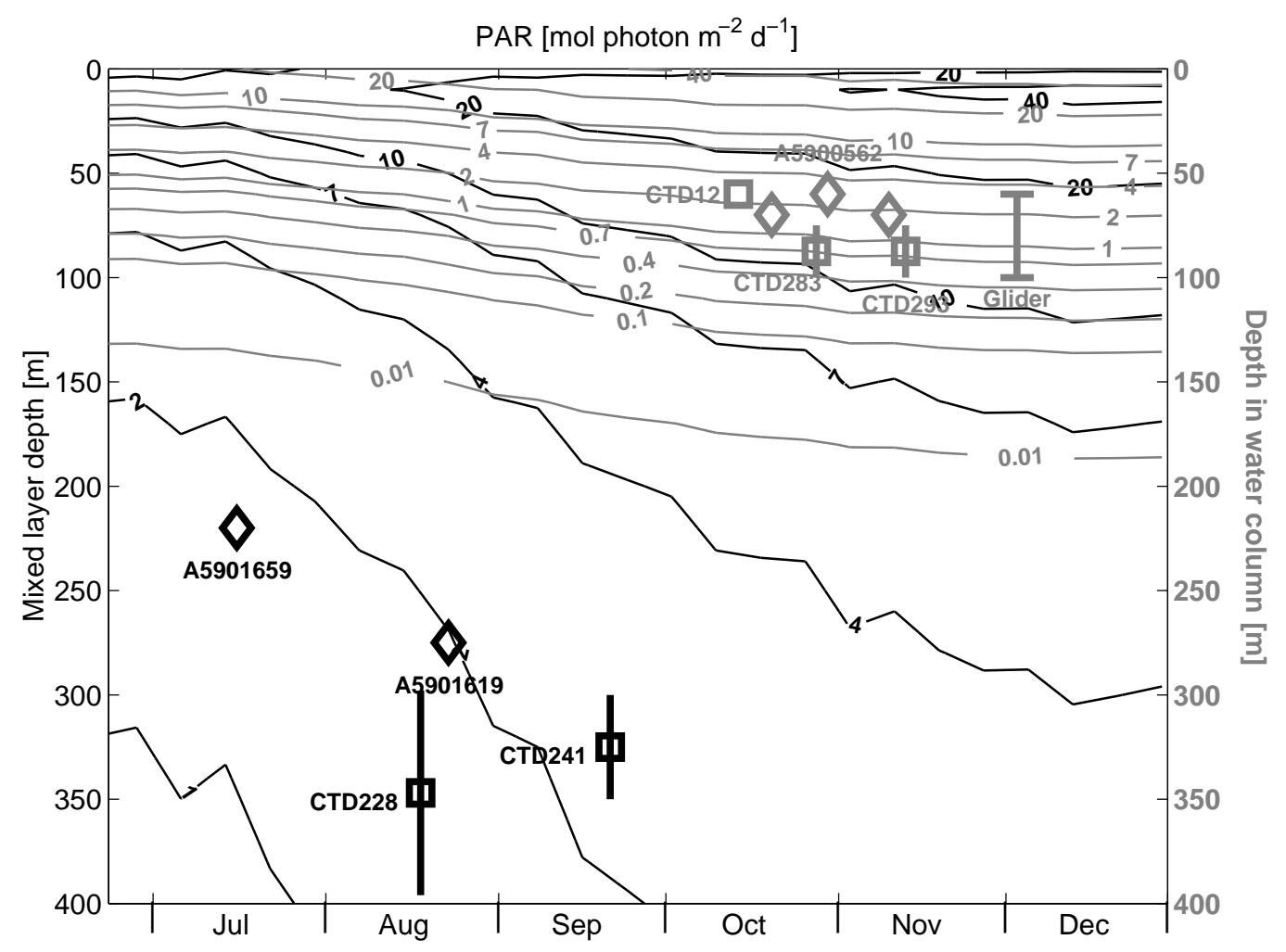

Fig. 11. Photosynthetically available radiation (PAR, mol photon $\mathrm{m}^{-2} \mathrm{~d}^{-1}$ ) integrated over the surface mixed layer (black contours) and at a constant depth in the water column (grey contours) from 20 June - 31 December at $33^{\circ} \mathrm{S} 154^{\circ} \mathrm{S}$. Surface PAR is determined from the 1997-2009 mean SeaWiFS 8 day, $9 \mathrm{~km}$ PAR product. Subsurface values are calculated using an attenuation coefficient of $0.045 \mathrm{~m}^{-1}$ and an azimuth angle based on orbital cycles (Brock, 1981; Baird et al., 2007). Observations are located on the x-dimension by time of year, and y-dimension by representative depth. Black symbols represent times when phytoplankton are mixed through the water column and experience a depth-integrated light field (1979: CTD228, CTD241; 2008: Argo floats A5901659 and A5901619). Grey symbols represent times when phytoplankton are held at one depth by the pyncocline (1979: CTD283, CTD293; 2008: CTD12, Argo float A5900562 and the Slocum glider). Error bars on the 1979 CTDs are a line between the deepest bottle sample in the surface mixed layer and the shallowest bottle below it. 


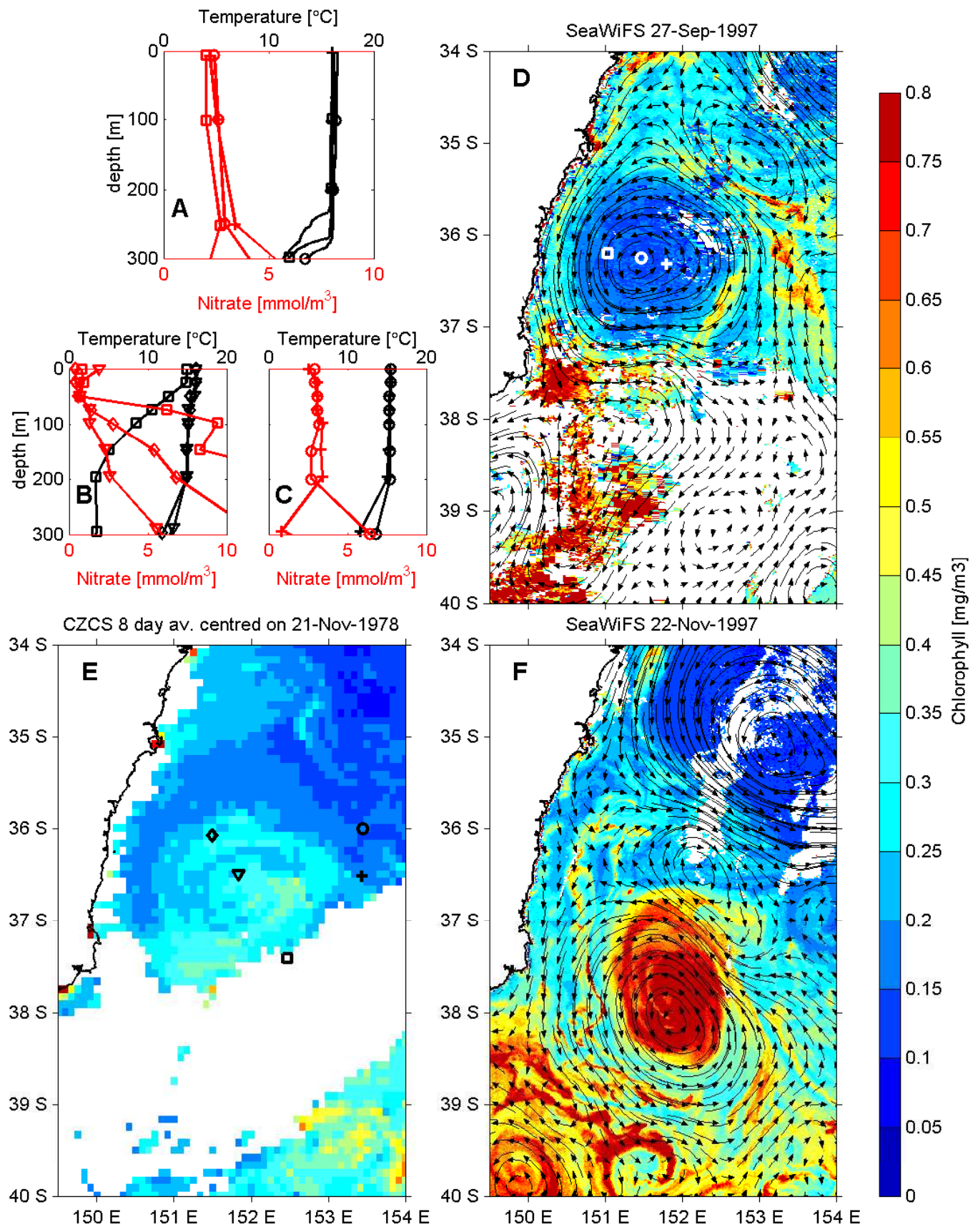

Fig. 12. Increasing productivity in two EAC WCEs as a result of the surface capping. In situ vertical profiles of temperature (black) and nitrate (red) from A. 1-3 October 1997, RV Franklin 199708 (Hitchman et al., 2000); B. Eddy J, 19-20 November 1978, RV Sprightly 197815 (Tranter et al., 1980); and C. Eddy J, 17-20 September 1978, RV Sprightly 197812 (Tranter et al., 1980). E. 8 day mean chl a concentration centred 21 November 1978 from the Coastal Zone Color Scanner (primarily a 18 November pass). Symbols in Panel E show locations of in situ vertical profiles in Panels B and C. SeaWiFS Level-3 daily chlorophyll $a$ on the 27 September (D) and 22 November 1997 (F). Arrows give 1 day Lagrangian geostrophic velocity paths for the 27 September and 20 November 1997 determined from the Topex/Poseidon and ERS2 altimeters. Symbols in Panel B show locations of in situ vertical profiles in Panel A. 